\title{
Article \\ Efficacy of Entomopathogenic Trichoderma Isolates against Sugarcane Woolly Aphid, Ceratovacuna lanigera Zehntner (Hemiptera: Aphididae)
}

\author{
Md. Shafiqul Islam ${ }^{1,2}$, Vijay Kumar Subbiah ${ }^{1}$ (D) and Shafiquzzaman Siddiquee ${ }^{1, *(D)}$ \\ 1 Biotechnology Research Institute, Universiti Malaysia Sabah, Jalan UMS, Kota Kinabalu 88400, Malaysia; \\ bsrishafiq81@gmail.com (M.S.I.); vijay@ums.edu.my (V.K.S.) \\ 2 Entomology Division, Bangladesh Sugarcrop Research Institute, Ishurdi, Pabna 6620, Bangladesh \\ * Correspondence: shafiqpab@ums.edu.my
}

check for

updates

Citation: Islam, M.S.; Subbiah, V.K.; Siddiquee, S. Efficacy of Entomopathogenic Trichoderma Isolates against Sugarcane Woolly Aphid, Ceratovacuna lanigera Zehntner (Hemiptera: Aphididae). Horticulturae 2022, 8, 2. https:// doi.org/10.3390/horticulturae8010002

Academic Editor: Giulia Giunti

Received: 16 November 2021

Accepted: 18 December 2021

Published: 21 December 2021

Publisher's Note: MDPI stays neutral with regard to jurisdictional claims in published maps and institutional affiliations.

Copyright: (C) 2021 by the authors. Licensee MDPI, Basel, Switzerland. This article is an open access article distributed under the terms and conditions of the Creative Commons Attribution (CC BY) license (https:// creativecommons.org/licenses/by/ $4.0 /)$.

\begin{abstract}
Ceratovacuna lanigera Zehntner (Hemiptera: Aphididae) is a destructive insect pest of sugarcane that is responsible for reducing the quality, yield, and sugar content. Ecofriendly methods of pest control, such as the use of biological control, is encouraged since it does not exhibit the harmful effects that are usually seen when using chemical-based pesticides. Here, we evaluated the efficacy of several entomopathogenic fungi isolates against $C$. lanigera under laboratory conditions. A total of seven isolates were obtained from agricultural soils that were collected from various locations from Sabah, Malaysia, using the insect bait method. Among the seven, four isolates (TMS114, TMS623, TMS628, and TMS707) were positively identified as T. harzianum (Hypocreales: Hypocreaceae), two isolates (TMS45, TMS321) as T. asperellum (Hypocreales: Hypocreaceae), and one isolate (TMS633) as T. hamatum (Hypocreales: Hypocreaceae) based on a combination of morphological characteristics and molecular data using ITS 1-5.8 S-ITS 2 regions of the rDNA. Four different concentrations $\left(1 \times 10^{5}\right.$, $1 \times 10^{6}, 1 \times 10^{7}$, and $1 \times 10^{8} \mathrm{~mL}^{-1}$ ) of conidia suspensions of the isolates were applied separately on nymphs and adults of $C$. lanigera. The results showed that mortality in both nymphs and adults was dependent on the conidia concentration and exposure time. Among the four concentrations, the highest mortality of C. lanigera was found to range from 59.99 to $75.70 \%$ for nymphs after $72 \mathrm{~h}$ and from 57.45 to $72.31 \%$ for adults after 6 days of treatments at the concentration of $1 \times 10^{8}$ conidia mL $^{-1}$. Trichoderma harzianum (TMS623) showed significantly highest mortality of $75.70 \%$ for nymphs and $72.31 \%$ for adults among the seven isolates. However, the nymph and adult mortality rates for the isolates were $70.00 \%$ \& $68.00 \%$ for TMS114, $66.42 \%$ \& $63.10 \%$ for TMS628, $67.85 \%$ \& $65.24 \%$ for TMS707, $61.42 \%$ \& $58.80 \%$ for TMS45, 59.99\% \& 57.45\% for TMS321 and $63.56 \%$ \& $60.91 \%$ for TMS633, respectively. For nymph mortality, T. harzianum (TMS623) showed a $\mathrm{LC}_{50}$ (lethal concentration) value of $6.30 \times 10^{5}$ conidia $\mathrm{mL}^{-1}$ and $\mathrm{LC}_{90}$ value of $3.01 \times 10^{9}$ conidia $\mathrm{mL}^{-1}$, respectively, and for adult mortality, the values were found of $6.16 \times 10^{5}$ conidia $\mathrm{mL}^{-1}$ for $\mathrm{LC}_{50}$ and $2.23 \times 10^{10}{\text { conidia } \mathrm{mL}^{-1}}^{-1}$ for $\mathrm{LC}_{90}$, respectively. The lethal time (LT) values for nymph and adult mortality were found of $42.65 \mathrm{~h}$ and 3.89 days for $\mathrm{LT}_{50}$ and $93.32 \mathrm{~h}$ and 8.70 days for $\mathrm{LT}_{90}$ by T. harzianum (TMS623). Therefore, T. harzianum (TMS623) showed more pathogenic potential against $C$. lanigera and can be further applied to determine its efficacy under field conditions. To our best knowledge, this is the first report of T. harzianum, T. hamatum, and T. asperellum species that are used as entomopathogenic fungi against sugarcane woolly aphid, C. lanigera.
\end{abstract}

Keywords: biocontrol; insect bait method; mortality; genus Trichoderma; insect pest control

\section{Introduction}

Sugarcane (Saccharum officinarum L.) is an important cash crop and it is the main source of processed sugar. Sugarcane woolly aphid (SWA), Ceratovacuna lanigera Zehntner (Hemiptera: Aphididae), is one of the most destructive insect pests of sugarcane [1]. Adult and nymphs of the sugarcane woolly aphid gather on the underside of leaves and suck 
the sap from the leaves. They produce honeydew that covers the entire upper surface of the leaf which causes the growth of sooty mold. With continuous infestation and sap sucking from the leaves, the plants will wilt and dry up from the tip downwards. This will eventually lead to the reduction of the length, girth, and weight of the sugarcane, as well as the quality, yield, and sugar content [2,3].

Chemical pesticides can leave poisonous residues in food products and harm nontarget organisms in the environment. Problems with chemical pesticides have led to a global interest in developing alternatives to these chemicals. The use of entomopathogenic fungi (EPFs) as bio-pesticides is a promising alternative to chemical-based pest control. Fungal biocontrol agents can mitigate and reduce the detrimental effects of chemical pesticides in the agriculture industry [4]. Entomopathogenic fungi have been extensively investigated as biological control agents of insect pests in attempts to develop sustainable crop protection [5].

Insect fungal diseases are common and widespread. More than 700 fungal species of 90 genera have the ability to cause diseases [6,7] at all the development phases of a wide range of insect pests in nursery, storage, greenhouses, and field conditions [8-11]. The pathogenicity of entomopathogenic fungi depends on the fungal species and the virulence of the strain [12]. Entomopathogenic fungi infect their insect host through the cuticle, penetrate them, and spread throughout the body. Once the fungus kills the host, it can grow from the host's cadaver and produce more spores, thus, increasing the chance of others getting infected [13].

Different species of entomopathogenic fungi such as Beauveria bassiana (Bals.-Criv.) Vuill. (Hypocreales: Cordycipitaceae) [14], Metarhizium anisopliae (Metschnikoff) Sorokin (Hypocreales: Clavicipitaceae) [15], Lecanicillium lecanii (Zare and Gams) (Hypocreales: Cordycipitaceae) [16], Paecilomyces lilacinus (Eurotiales: Trichocomaceae), Paecilomyces farinosus (Eurotiales: Trichocomaceae), Paecilomyces fumosoroseus (Hypocreales: Cordycipitaceae) [17], and Purpureocillium lilacinum (Thom) (Hypocreales: Ophiocordycipitaceae) [18] have been reported as pathogenic fungi against a wide variety of insect pests including different species of aphids.

The fungal genus Trichoderma (Hypocreales: Hypocreaceae) are usually cosmopolitan, exhibit high genetic diversity, and are commonly found in all geographical climatic areas of different habitats, including agricultural lands, marshes, and deserts [19-21]. Trichoderma species can be easily isolated from natural soil, decaying organic plant material, and wood and classified as imperfect fungi belonging to the order Hypocreales of Ascomycota [22,23].

Trichoderma reproduces and grows rapidly in various nutrient sources such as potato dextrose agar (PDA), malt agar (MA), and Czapek dox agar (CDA) and produces coni$\mathrm{dia} /$ spores of different shades that are characterized by green color $[24,25]$ and some species produce thick-walled chlamydospores [26]. Trichoderma was first described as a biological agent in the early 1930s, as a parasite of soil pathogenic fungi in which Trichoderma lignorum (Hypocreales: Hypocreaceae) was found as an inhibitor of Phytophthora parasitica (Peronosporales: Peronosporaceae), Rhizoctonia solani (Cantharellales: Ceratobasidiaceae), Rhizopus spp. Sclerotium rolfsii (Polyporales: Atheliaceae), and Pythium spp. [27].

In addition, Trichoderma species have been used widely as antagonistic fungal agents against various pests as well as a plant growth promoter [13]. Several Trichoderma spp. have been reported as potential biological control agents against different insect species. Among them, the cotton aphid, Aphis gossypii (Glover) (Hemiptera: Aphididae), cotton leaf hopper (Jassid), Amrasca bigutulla bigutulla (Hemiptera: Cicadellidae), and larvae of the Oryctes rhinoceros (Coleoptera: scarabaeidae) on palm oil plants can be controlled by Trichoderma spp. [13,28-30]. Trichoderma spp. Are also effective for the control of Helicoverpa armigera (Lepidoptera: Noctuidae) in chickpea, aphid, Schizaphis graminum Rondani (Hemiptera: Aphididae) (major pests of cereal crops) [31,32], Spanish vineyards, Xylotrechus arvicola (Olivier) (Hemiptera: Aphididae) [33], and cabbage aphid, Brevicoryne brassicae (Hemiptera: Aphididae) [34]. 
Since different species of insect pests can be controlled by different species of entomopathogenic fungi (EPFs), this suggests that EPFs are useful for the biological control of insect pests. Therefore, it is hypothesized that virulent isolates of EPFs could potentially be used as agents to control and inhibit the growth of sugarcane woolly aphids (SWA). As such, we attempted to identify these virulent isolates from various agricultural soils that were planted with different crops and to determine its efficacy (with different concentrations of conidia suspensions) against sugarcane woolly aphid nymphs and adults under laboratory conditions.

\section{Materials and Methods}

\subsection{Collection of Soil Samples}

A total of seven soil samples were collected from agricultural soils that were planted with pumpkin, brinjal (two samples from two different locations), okra, sugarcane, maize, and mustard, respectively. The samples were taken from cultivated lands at Tuaran, Menggatal, Penampang, and Papar in Sabah, Malaysia. The soil samples were taken at a depth of approximately $10-15 \mathrm{~cm}$ [35] using a sterilized garden shovel after removing debris from the surface. To avoid possible cross-contamination, the garden shovel was sterilized with $70 \%$ ethanol immediately after each soil sample was taken. Approximately $500 \mathrm{~g}$ of soil were taken randomly from four different sites at each agricultural plot. Next, the four soil samples were mixed together and $2.0 \mathrm{~kg}$ of total weight was collected. The samples were placed in labeled polyethylene bags, sealed with an elastic band, and taken to the Microbiology laboratory of the Biotechnology Research Institute of University of Malaysia Sabah (UMS) as soon as possible and stored at $4{ }^{\circ} \mathrm{C}$ for subsequent analysis.

\subsection{Collection of Insect Samples}

According to Zimmermann [36], mealworm larvae, Tenebrio molitor L. (Coleoptera: Tenebrionidae) are traditional bait insects for isolation of entomopathogenic fungi by insect bait method as they are easy rearing and susceptible to the fungi. Thus, Tenebrio molitor larvae were obtained from Harvest Fish \& Agriculture Sdn. Bhd., Penampang, Sabah, Malaysia and used in the insect bait method. The larvae were then brought to the Microbiology laboratory of BRI, UMS, in clean vials for subsequent assay.

\subsection{Isolation of Fungi by Insect Bait Method (IBM)}

The fungi were isolated from soil samples using the insect bait method (IBM) following by Zimmermann [36]. The soil samples were cleaned from roots and mixed homogeneously, after which an approximately $400 \mathrm{~g}$ was placed in a sterilized plastic box $(13 \mathrm{~cm} \times 13 \mathrm{~cm} \times 10 \mathrm{~cm})$. A total of four replicates were performed for each soil sample, each labeled according to sample number [37]. Soil samples were moistened with sterile water and then 10 pre-heated mealworm larvae were placed into each box and the larvae were covered with moist soil. The boxes were covered with lids with a mesh cloth and incubated at $22{ }^{\circ} \mathrm{C}$ in the dark and inverted every day during the first week for providing maximum contact of spores to larvae. The samples were monitored for the first time after 5 days and this was repeated every 3-4 day for 3 weeks after the initial baiting and the growth of fungi to the larvae was inspected [38].

The larvae that were infected by entomopathogenic fungi were removed from the soil and the fungi were isolated according to Zimmermann $[36,38]$. The infected larvae were surface-sterilized by soaking $1 \%(v / v)$ sodium hypochlorite $(\mathrm{NaClO})$ solution for $3 \mathrm{~min}$, rinsed three times in sterile water, and dried on sterile filter paper.

The surface-sterilized larvae were cut into small pieces (5-7 pieces) and each small piece of larva was placed in a Petri dish $(90 \mathrm{~mm}$ diameter) containing selective medium, sabouraud dextrose agar + yeast $(0.2 \%)$ (SDAY) [39]. Streptomycin $(0.06 \%)$ and tetracycline $(0.005 \%)$ were used as bacterial inhibitors. The Petri dish was incubated at $28{ }^{\circ} \mathrm{C}$ and a humidity of $70 \%$. After 3 days of incubation, the fungal colonies were visible and were 
then transferred into SDAY medium for fungal culture. After that, the pure cultures were maintained in SDAY medium and subsequently stored at $4{ }^{\circ} \mathrm{C}$ for further use.

\subsection{Morphological Characterization}

Morphological characterization of the fungi isolates was carried out following the macroscopic and microscopic characteristics of the culture based on the procedure of Siddiquee [35].

\subsubsection{Macroscopic Characterization}

To identify the fungi species, several groups of fungi colonies were analyzed by morphological characteristics. The isolates were re-cultured aseptically from the stock slants in SDAY in a Petri dish $(90 \mathrm{~mm})$ and incubated at $28^{\circ} \mathrm{C}$, with a humidity of $70 \%$ for 5-7 days, and the isolates were monitored every day. The isolates were categorized based on the following macroscopic characteristics: colony growth rate, colony color in both sides of the Petri dish, colony appearance, and the mycelium density [35].

\subsubsection{Microscopic Characterization}

The slide culture technique was followed for microscopic observation of the isolates according to Siddiquee [35]. The slide culture was made in the Petri dish $(90 \mathrm{~mm})$ containing a U-shaped glass rod on the sterile moistened filter paper. A thin film of an agar block ( $1 \mathrm{~cm}$ square) was excised out from the agar plate and transferred to the center of the slide and placed on the glass rod. A total of four edges of the agar block were inoculated with fungal spores or mycelia fragments using a sterile inoculating loop. A sterile cover slip was then placed on the upper surface of the agar cube. Next, the slide was incubated at room temperature for 3 days and then observed under a light microscope (Olympus CX31) with $100 \times$ and $400 \times$ magnifications. The observations were focused on the size, shape and color of the conidia, the branching pattern of the conidiophores, and the presence of phialides [35].

\subsection{Fungi Identification Using the DNA Sequences of the ITS 1-5.8 S-ITS 2 Regions of the rDNA}

\subsubsection{DNA Amplification and Visualization}

Fungi genomic DNA was extracted by the cetyltrimethylammonium bromide (CTAB) method according to Cubero [40]. The polymerase chain reaction (PCR) was performed to amplify ITS 1-5.8 S-ITS 2 regions of the rDNA using primers ITS1 (5'-TCC GTA GGT GAA CCT GCG G-3') and ITS4 (5'-TCC TCC GCT TAT TGA TAT GC-3') [41]. The PCR reactions were performed with an automated thermal cycler (PTC-200 Peltier Thermal Cycler) using $25 \mu \mathrm{L}$ of reaction mixtures containing $2.5 \mu \mathrm{L}$ of $10 \times$ PCR buffer, $2.0 \mu \mathrm{L}$ of $25 \mathrm{mM}$ magnesium chloride $\left(\mathrm{MgCl}_{2}\right), 0.5 \mu \mathrm{L}$ of $10 \mathrm{mM}$ PCR deoxynucleotides triphosphate mix (dNTPs), $0.25 \mu \mathrm{L}$ of 5 Units of Taq DNA polymerase, $0.625 \mu \mathrm{L}$ of each $10 \mu \mathrm{M}$ primers (ITS1 and ITS4), $16.5 \mu \mathrm{L}$ of sterilized distilled water $\left(\mathrm{ddH}_{2} \mathrm{O}\right)$, and $2 \mu \mathrm{L}$ of $100 \mathrm{ng} / \mu \mathrm{L}$ template DNA. The ITS 1-5.8 S-ITS 2 regions of the rDNA were amplified according to the following PCR protocols: initial denaturation at $95^{\circ} \mathrm{C}$ for $4 \mathrm{~min}$, followed by 39 cycles of denaturation at $95^{\circ} \mathrm{C}$ for $45 \mathrm{~s}$, primer annealing at $56{ }^{\circ} \mathrm{C}$ for $45 \mathrm{~s}$, and extension at $72{ }^{\circ} \mathrm{C}$ for $1 \mathrm{~min}$. The amplification was completed with one additional step of final extension at $72{ }^{\circ} \mathrm{C}$ for $10 \mathrm{~min}$.

A total of of $5 \mu \mathrm{L}$ of the PCR products were electrophoresed in $1 \%(w / v)$ of agarose gel in $1 \times$ Tris-borate-EDTA (TBE) buffer ( $89 \mathrm{mM}$ Tris Base, $89 \mathrm{mM}$ Boric acid, and $2 \mathrm{mM}$ EDTA, pH 8.0) at $70 \mathrm{~V}$ for $50 \mathrm{~min}$. The approximate sizes of the amplified fragments were determined by comparing them with a $100 \mathrm{bp}$ DNA ladder (GeneRuler, $100 \mathrm{bp}$ Plus DNA Ladder, 1st BASE). The gel was stained with Ethidium Bromide (EtBr) for $15 \mathrm{~min}$ and observed visually under UV light and photographed using the AlphaImager ${ }^{\circledR} \mathrm{HO}$ (Alpha Innotech, TX, United States). 


\subsubsection{Sequencing and Phylogenetic Analysis}

The successfully amplified PCR products were purified using the QIAquick ${ }^{\circledR}$ PCR Purification Kit (QIAGEN) according to the manufacturer's instructions. DNA sequencing was performed at the Genomic laboratory of the BRI, UMS, using the ABI3130 DNA sequencer. The sequences of the ITS 1-5.8 S-ITS 2 regions were compared with information from public database in NCBI (National Center for Biotechnology Information, Bethesda, MD, USA) (http:/ / www.ncbi.nlm.nih.gov/BLAST / (accessed on 16 August 2021)). According to the BLAST results, the sequences were taken based on the similarity value $\geq 97 \%$ with known sequences in the NCBI database [42].

Computer-aided alignment of the ITS 1-5.8 S-ITS 2 regions sequence was performed using the BioEdit Sequence Alignment Editor. The alignment was then optimized manually. Single gaps were treated as a fifth nucleotide (A, C, G, T and gaps). All gap positions within the alignment exceeding a single base in length were replaced by question marks. Sequence insertions without homology to any of the other sequences were deleted in the alignment and a single base was left over causing a minimal gap. In this way, the gaps of all sizes were weighted equally corresponding to a hypothetical single evolutionary event. Finally, alignment adjustments were made manually to remove artificial gaps. The aligned sequences were visually inspected and adjustments were made to improve the alignment.

The ITS 1-5.8 S-ITS 2 phylogenetic tree of the rDNA was performed by comparing it with the sequences from NCBI. The trees were constructed according to the unweighted pair-group method based on the arithmetic average (UPGMA) [43] using molecular evolutionary genetics analysis (MEGA X) software version 10 [44]. The UPGMA tree was used as it produced a rooted tree with constant rate of evolution and was suitable for this purpose. The reliability and interior branches and the validity of the trees were tested with 10,000 replications using bootstrap. The distances were computed using the Kimura-2 (K2P) parameter [45].

\subsection{Fungi Conidia Suspensions Preparation}

The conidia suspensions were prepared from selected fungal isolates according to the method that was described by Javed [46] and Umaru [47] with some modifications. The fungi isolates were re-cultured in SDAY medium from pure culture stock slants and incubated at $28{ }^{\circ} \mathrm{C}$ for 14 days. The conidia were harvested by carefully scraping the surface with a sterile spatula and were suspended in $10 \mathrm{~mL}$ of sterile $0.02 \%(v / v)$ Tween-80 solution. The suspension of each plate was placed separately in a $100 \mathrm{~mL}$ beaker and mixed thoroughly to obtain a homogeneous mixture. The suspension of the conidia was sieved with a sterile gauze. The density of conidia of the suspension was calculated by using a neubauer haemocytometer under the microscope and adjusted to the concentrations of $1 \times 10^{8}, 1 \times 10^{7}, 1 \times 10^{6}$, and $1 \times 10^{5}$ conidia $\mathrm{mL}^{-1}$, and stored at $4{ }^{\circ} \mathrm{C}$ for the bioassay experiment.

\subsection{Sugarcane Woolly Aphids Rearing and Bioassay Chamber Preparation}

Sugarcane leaves that were attached with nymphs and adults were collected from natural infestation of sugarcane experimental plots that had been previously set up at the net house of plant transgenic facility site of University Malaysia Sabah (UMS), Kota Kinabalu, Sabah, Malaysia, at a latitude of $6^{\circ} 02^{\prime} 7.20^{\prime \prime} \mathrm{N}$ and longitude of $116^{\circ} 07^{\prime} 4.20^{\prime \prime} \mathrm{E}$. The nymphs and adults were reared separately in plastic containers $(25 \mathrm{~cm} \times 16 \mathrm{~cm} \times 10 \mathrm{~cm})$ at a temperature of $25^{\circ} \mathrm{C}$, with a humidity of $70 \pm 10 \%$, and a photoperiod ratio of 2:1 (Light:Dark) [46,47]. As a natural diet, fresh sugarcane leaves were used to feed the aphids properly which were replaced after $24-48 \mathrm{~h}$. The nymphs and adults were collected from rearing containers and used for a bioassay [46,48].

The bioassay chamber was prepared using plastic containers $(25 \mathrm{~cm} \times 16 \mathrm{~cm} \times 10 \mathrm{~cm})$ that were covered with a mesh cloth to allow for adequate ventilation. To maintain sufficient moisture in the bioassay chamber, sterilized wet filter paper was used at the bottom of the container. Fresh sugarcane leaves (about $20 \mathrm{~cm}$ length) were sterilized with $0.005 \%$ sodium 
hypochlorite for $2 \mathrm{~min}$ and then rinsed with sterilized water and placed in the center of each container. The sterilized, moist cotton was attached around the opening end of the leaves to provide moisture and protection of the leaves from drying in the chambers. The adults and nymphs that were attached to the sugarcane leaves were collected from the rearing containers and surface sterilized gently for $1 \mathrm{~min}$ with $0.001 \%$ sodium hypochlorite in water $(v / v)$ and rinsed with sterilized water and then transferred to fresh leaves, which were kept in the bioassay chambers, using soft camel hairbrush.

A total of 50 nymphs per leaf were used and placed in a single bioassay chamber for each treatment. A total of three replicates were performed for each treatment in three separate chambers. For the adults, the same procedure was followed in separate chambers [46,49].

\subsection{Efficacy Determination Bioassay}

The efficacy of the fungal isolates against $C$. lanigera nymphs and adults was determined according to the methods that were described by Mukherjee [29], Umaru [47], and Shrestha [50]. To determine the efficacy, four different concentrations $\left(1 \times 10^{5}, 1 \times 10^{6}\right.$, $1 \times 10^{7}$, and $1 \times 10^{8}$ conidia $\mathrm{mL}^{-1}$ ) of conidia suspension of each isolate were applied separately to the nymphs and adults, which were placed on fresh sugarcane leaves in the separate bioassay chamber. A total of $1 \mathrm{~mL}$ of each concentration was applied separately to 50 nymphs and 50 adults, respectively. The topical application was conducted uniformly by using a micropipette (Eppendorf, Enfield, CT, USA).

A $0.02 \%$ Tween 80 solution was applied in the control chamber. A total of three replications were taken for each treatment including the control. All of the fungi isolates were applied in bioassay chambers and then covered with mesh lids and kept in the Microbiology Laboratory of BRI, UMS, at a temperature of $25^{\circ} \mathrm{C}$, humidity of $70 \pm 10 \%$, and a photoperiod ratio of 2:1 (Light:Dark) [46,47]. Furthermore, to provide sufficient moisture to the bioassay chamber, the filter paper that was placed at the bottom of the container was sprayed with sterilized distilled water as needed. Fresh new sugarcane leaves were placed near both sides of the old leaves (after 24-48 h) as a food source so that the nymphs and adults could always have enough food. The mortality was counted from 12 to $72 \mathrm{~h}$ at $12 \mathrm{~h}$ intervals for the nymphs and 1 to 6 days for the adults at 1 day intervals [49]. The nymph and adult mortality rates were counted separately and death was confirmed only for those that appeared to have fungal growth [51]. The mortality of each treatment was calculated and corrected using Abbott's formula [52].

\subsection{Determination of Lethal Concentrations and Lethal Times}

Lethal concentrations $\left(\mathrm{LC}_{50} \& \mathrm{LC}_{90}\right)$ and lethal times $\left(\mathrm{LT}_{50} \& \mathrm{LT}_{90}\right)$ of the fungi isolates were determined against the nymphs and adults. The bioassay was conducted with four different conidia concentrations (Described in Section 2.8). The $\mathrm{LC}_{50} \& \mathrm{LC}_{90}$ values were calculated with different concentrations of $1 \times 10^{5}, 1 \times 10^{6}, 1 \times 10^{7}$, and $1 \times 10^{8}$ conidia $\mathrm{mL}^{-1}$ and the mortalities were counted at $72 \mathrm{~h}$ for the nymphs and 6 days for the adults. The $\mathrm{LT}_{50} \& \mathrm{LT}_{90}$ values were calculated using a concentration of $1 \times 10^{8}$ conidia $\mathrm{mL}^{-1}$ with different times of 24 to $72 \mathrm{~h}$ for nymphs and 2 to 6 days for adults.

\subsection{Statistical Analysis}

The laboratory experiments were conducted according to completely randomized design (CRD) with eight treatments, including controls, and three replicates were performed for each treatment. The mortality data for the nymphs and adults were corrected using Abbott's formula [52]. The final data were analyzed by analysis of variance (ANOVA) and the means were compared by the least significant difference (LSD) test at a significance level of $5 \%$ using Statistix 10 software. The lethal concentration $\left(\mathrm{LC}_{50} \& \mathrm{LC}_{90}\right)$ values and lethal time $\left(\mathrm{LT}_{50} \& \mathrm{LT}_{90}\right)$ values were calculated according to Finney's Probit analysis table [53] and regression analysis using Microsoft Office Excel 2007. The graphs were prepared using R software (version: 4.1). 


\section{Results}

\subsection{Fungi Isolates}

A total of 26 fungi isolates were found by the insect bait method from seven agricultural soils of Sabah, Malaysia (Table 1), based on colony colors, colony appearance, growth rate, and mycelium density. Out of the 26 isolates, 7 were selected based on the efficacy test against nymphs and adults of sugarcane woolly aphid. Among the seven isolates, four (TMS114, TMS623, TMS628, and TMS707) were identified as Trichoderma harzianum, two isolates (TMS45 and TMS321) as Trichoderma asperellum, and one isolate (TMS633) as Trichoderma hamatum based on a combination of morphological characteristics and gene sequencing analysis of the ITS 1-5.8 S-ITS 2 regions of the rDNA (Table 1).

Table 1. Details of fungi isolates used in the study.

\begin{tabular}{cccccc}
\hline Isolates Code & Fungi Species & Identity Percentages & $\begin{array}{c}\text { GenBank Accession } \\
\text { Number }\end{array}$ & Vegetation & Geographic Origin \\
\hline TMS114 & T. harzianum & 100.00 & MN258613.1 & Brinjal & $\begin{array}{c}\text { Menggatal, Sabah, } \\
\text { Malaysia }\end{array}$ \\
\hline TMS623 & T. harzianum & 100.00 & MK738146.1 & Pumpkin & $\begin{array}{c}\text { Tuaran, Sabah } \\
\text { Malaysia }\end{array}$ \\
\hline TMS628 & T. harzianum & 99.80 & KJ191344.1 & Okra & $\begin{array}{c}\text { Penampang, Sabah, } \\
\text { Malaysia }\end{array}$ \\
\hline TMS707 & T. harzianum & 100.00 & KC847189.1 & Sugarcane & Papar, Sabah Malaysia \\
\hline TMS45 & T. asperellum & 100.00 & MT367901.1 & Mustard & $\begin{array}{c}\text { Menggatal, Sabah, } \\
\text { Malaysia }\end{array}$ \\
\hline TMS321 & T. asperellum & 99.78 & MN452469.1 & Brinjal & $\begin{array}{c}\text { Penampang, Sabah, } \\
\text { Malaysia }\end{array}$ \\
\hline TMS633 & T. hamatum & 100.00 & MT256289.1 & Maize & $\begin{array}{c}\text { Tuaran, Sabah } \\
\text { Malaysia }\end{array}$ \\
\hline
\end{tabular}

\subsection{Morphological Characterization}

The isolates were characterized based on the colony appearance, growth pattern, branching pattern in conidiophores, size of conidia, and phialides as shown in Figure 1.

Trichoderma harzianum:

A total of four isolates (TMS623, TMS114, TMS628, and TMS707) were characterized as T. harzianum in accordance with the following description.

Macroscopic characteristics:

Trichoderma harzianum was observed to cause intense coloration of the agar from yellow to dark orange pigments in mature colonies after five days of incubation in SDAY at $28{ }^{\circ} \mathrm{C}$ (Figure 1A). An indistinct sweet coconut odor was detected from the isolates. The mycelium was initially smooth, watery white and sparse, until cottony aerial mycelium was produced.

Microscopic characteristics:

The conidiophores were spread to the top in pyramidal fashion and highly branched (Figure 1C). The phialides were flask shaped and typically short and wide in the middle with an average length of 4 to $6 \mu \mathrm{m}$. The conidia generally tend to be globose to subglobose in shape with an average length of 2 to $3 \mu \mathrm{m}$ and pale green in color.

\section{Trichoderma hamatum:}

A total of one isolate (TMS633) was characterized as T. hamatum according to the following description:

\section{Macroscopic characteristics:}

The colonies of T. hamatum were observed to grow rapidly and covered the entire whole Petri dishes within four to five days after incubation in SDAY at $28^{\circ} \mathrm{C}$ (Figure 1D). It produced a white-color aerial mycelia with yellow conidiation in the centre of the plate and grown densely. 


\section{Microscopic characteristics:}

The conidiopores were observed to be highly branched in an irregular pattern (Figure 1F). The phialidides were formed from short lateral branches at the base of the elongation, were generally ellipsoildal to ovoidal with an average length of 5-7 $\mu \mathrm{m}$, and a width of 3-4 $\mu \mathrm{m}$ at the widest point. The conidia were observed to be green, smooth-walled, and ellipsoidal. The average length of the conidia obtained from 4 to $5 \mu \mathrm{m}$.

Trichoderma asperellum

A total of two isolates (TMS45 and TMS321) were characterized as T. asperellum based on the following description.

Macroscopic characteristics:

The colonies of the T. asperellum isolates that were grown in SDAY at $28{ }^{\circ} \mathrm{C}$ for five days formed one or two concentric rings near the inoculation zone with a dense production of conidia (Figure 1G). Dark green conidia were observed to grow towards the center and the margin.
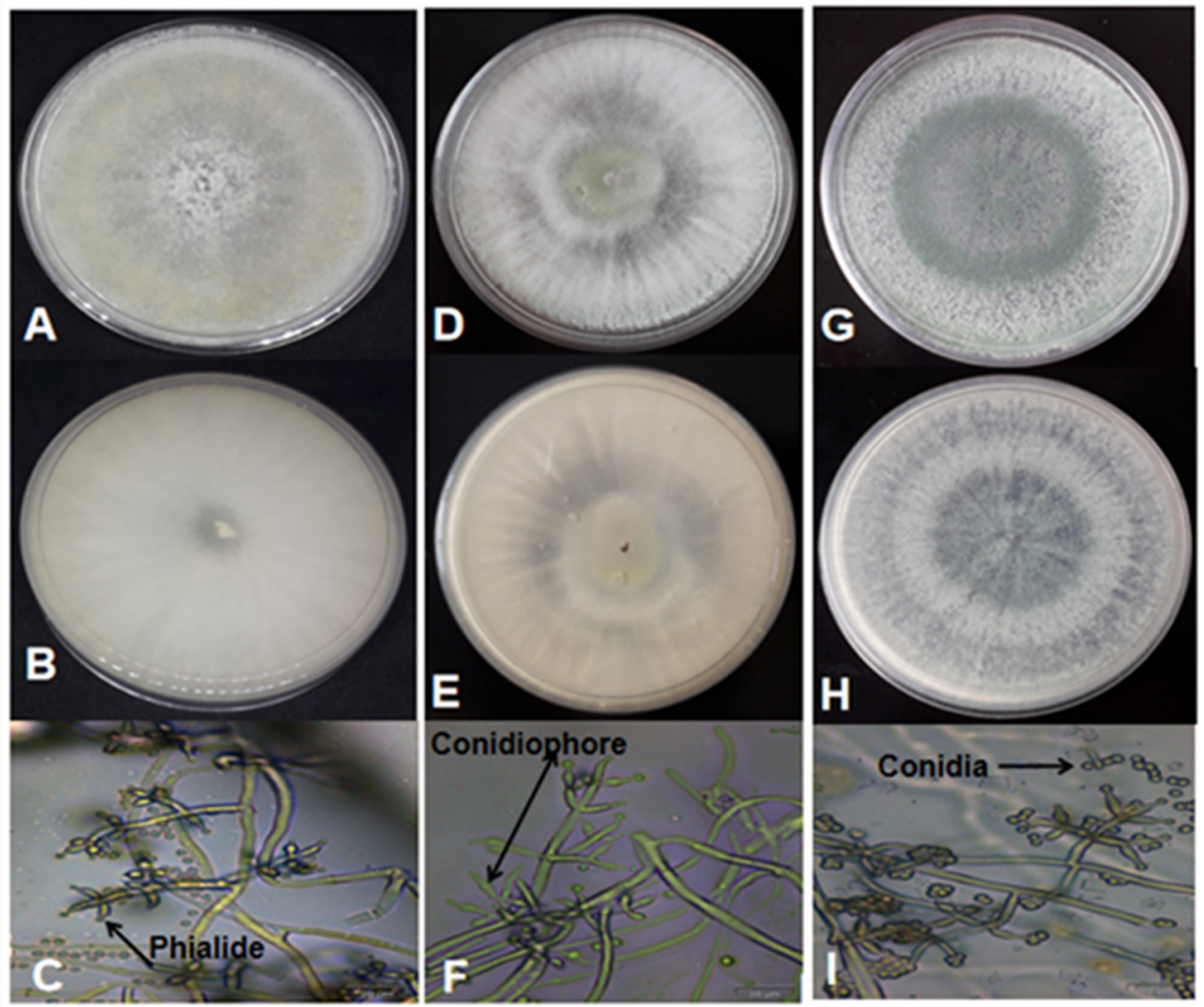

Figure 1. The morphological (macroscopic and microscopic) characteristics of three Trichoderma species: (A,B) Front colony and reverse of T. harzianum (TMS623); (D,E) the front colony and reverse of T. hamatum (TMS633); (G,H) the front colony and reverse of T. asperellum (TMS45). Colony characteristics were observed at 5 days incubation in SDAY at $28^{\circ} \mathrm{C} ;(\mathbf{C}, \mathbf{F}, \mathbf{I})$ The conidiophores with phialides and conidia of T. harzianum (TMS623), T. hamatum (TMS633), and T. asperellum (TMS45), respectively, observed with $400 \times$ magnification.

\section{Microscopic characteristics:}

The conidiophores are highly branched and symmetrically arranged (Figure 1I). Phialides are produced at the tips of the primary, secondary, and tertiary branches, rarely straight along the length of the branches, typically in whorls of $2-4$ phialides. The ampuliform were slightly enlarged in the middle, an average length of $8 \mu \mathrm{m}$. The conidia was observed as a dark green color, globose to subglobose or ovoidal, in the size of 3-4 $\mu \mathrm{m}$. 


\subsection{Molecular Analysis}

\subsubsection{DNA Amplification}

The genomic DNA of entomopathogenic Trichoderma isolates was amplified using ITS1 and ITS4 primers. An approximately $600 \mathrm{bp}$ of the ITS 1-5.8 S-ITS 2 regions of rDNA were successfully amplified among seven Trichoderma isolates (Figure 2).

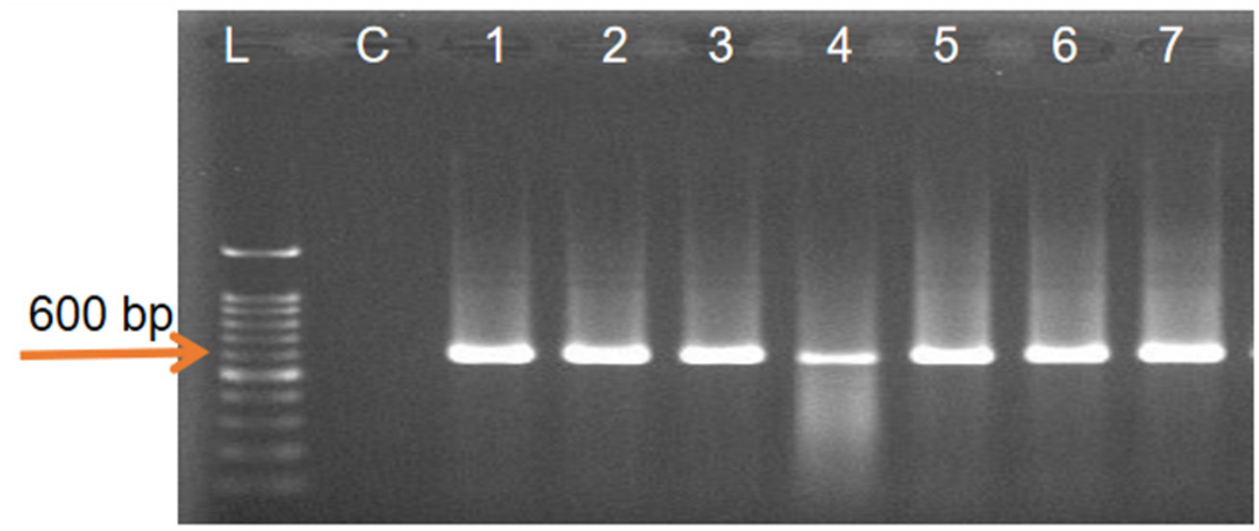

Figure 2. Picture of the $1 \%$ agarose gel showing the PCR products amplification of the ITS 1-5.8 S-ITS 2 regions of rDNA of Trichoderma isolates with the expected amplicon size (600 bp). Lane L: $100 \mathrm{bp}$ DNA Ladder. Lane C: The negative control. Lane 1: TMS623, Lane 2: TMS114, Lane 3: TMS628, Lane 4: TMS707, Lane 5: TMS633, Lane 6: TMS45, and Lane 7: TMS321.

\subsubsection{Sequence Analysis of the ITS 1-5.8 S-ITS 2 Regions of the rDNA}

The sequences of the ITS 1-5.8 S-ITS 2 regions were aligned using the BioEdit Sequence Alignment Editor and a consensus sequence was generated. All of the gene sequences were compared to the NCBI database using BLAST (available online at http:/ / www.ncbi.nlm. nih.gov (accessed on 16 August 2021)) to identify fungi species based on the ITS 1-5.8 S-ITS 2 regions of the rDNA. All the isolates showed the similarity values between $99-100 \%$ with known sequences in the NCBI database. Therefore, among the seven isolates, four (TMS114, TMS623, TMS628, and TMS707) were identified as T. harzianum, two isolates (TMS45 and TMS321) as T. asperellum, and one isolate (TMS633) as T. hamatum.

\subsubsection{Phylogenetic Analysis}

The phylogenetic tree was constructed using MEGA $X$ software based on the sequence data of the ITS 1-5.8 S-ITS 2 regions of the rDNA. The phylogenetic analysis showed that the seven fungi isolates had the similarities to the previously registered existing sequences on the GenBank database (Figure 3). According to the tree, three major groups were formed. A total of four isolates (TMS114, TMS623, TMS628, and TMS707) were clustered belong to T. harzianum, two isolates (TMS45 and TMS321) were clustered of T. asperellum, and one isolate (TMS633) was clustered of T. hamatum.

\subsection{Efficacy Evaluation}

The efficacy test was performed for the selection of potential Trichoderma isolates against $C$. lanigera. The data were obtained from bioassay among isolates against nymphs and adults that were found varying degrees of effectiveness.

\subsubsection{Efficacy Evaluation against Nymphs}

Trichoderma isolates showed different mortality of C. lanigera nymphs during $72 \mathrm{~h}$ of treatment with four different conidia concentrations: in $1 \times 10^{5}, 1 \times 10^{6}, 1 \times 10^{7}$, and $1 \times 10^{8}$ conidia $\mathrm{mL}^{-1}$. 


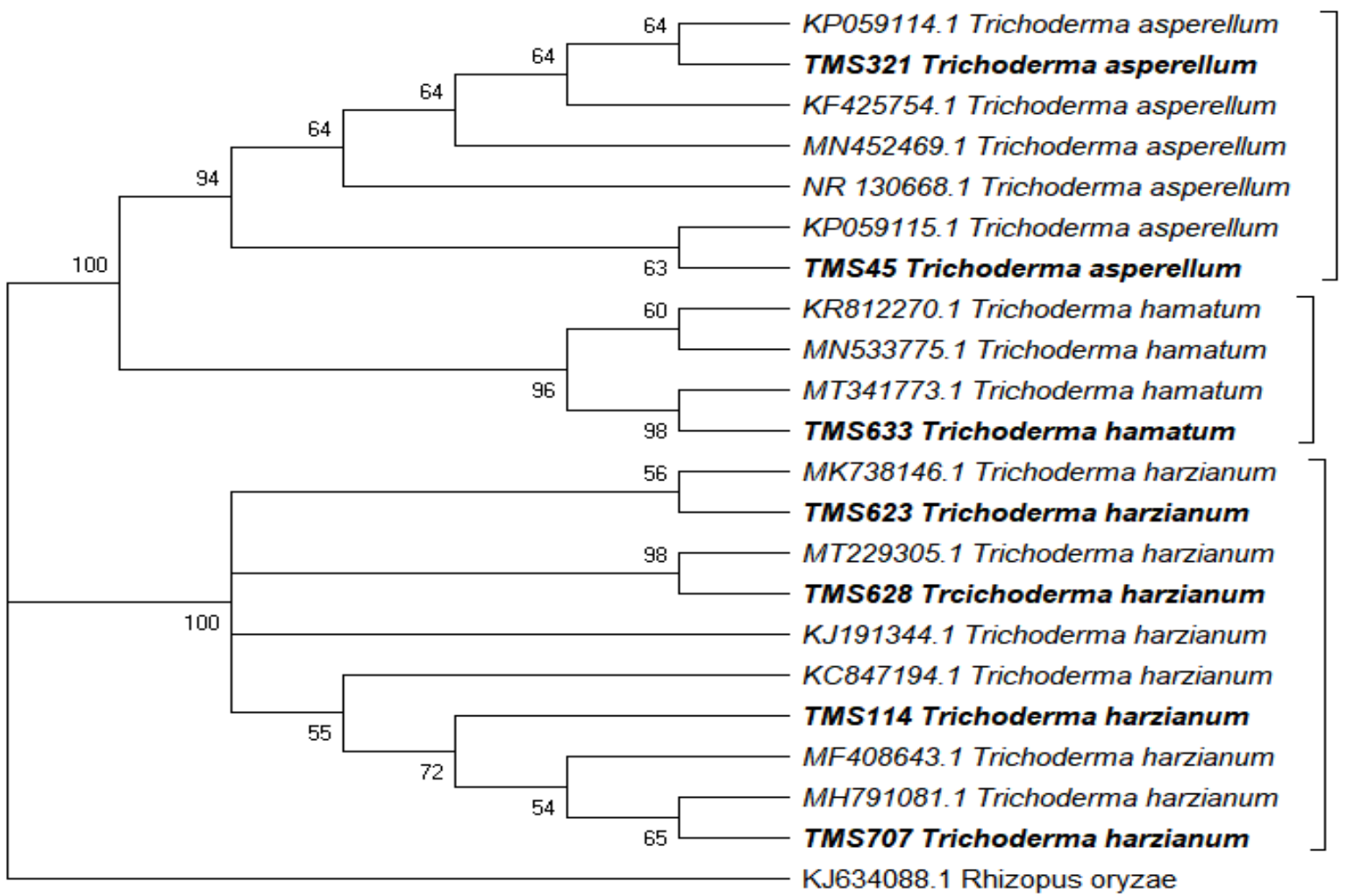

Figure 3. The phylogenetic relationship of the isolates according to the UPGMA method using gene sequences of ITS 1-5.8 S-ITS 2 regions of the rDNA. Bootstrap values that are shown by the nodes are based on 10,000 replicates. Bold lettering marked our isolates that were used in this study. Rhizopus oryzae (Mucorales: Mucoraceae) acts as the outgroup of this analysis.

After $24 \mathrm{~h}$ of treatment, 13.33\% mortality was found by T. harzianum (TMS623) in $1 \times 10^{8}$ conidia $\mathrm{mL}^{-1}(F=45.20, p<0.001)$ suspension. No nymph mortality was found in the controls up to $36 \mathrm{~h}$ of treatment (Figure 4 ).

The concentrations of conidia suspension affected mortality. The mortality ranges of the isolates were found from 26.59 to $39.54 \%$ in $1 \times 10^{5}$ conidia $\mathrm{mL}^{-1}(F=35.78, p<0.001)$, from 33.57 to $46.00 \%$ in $1 \times 10^{6}$ conidia $\mathrm{mL}^{-1}(F=76.84, p<0.001)$, and from 53.56 to $69.52 \%$ in $1 \times 10^{7}$ conidia $\mathrm{mL}^{-1}(F=127.24, p<0.001)$ suspensions. The highest mortality rates ranged from 59.99 to $75.70 \%$ of the $C$. lanigera nymphs in $1 \times 10^{8}$ conidia $\mathrm{mL}^{-1}(F=178.53$, $p<0.001$ ) within the same treatment period of $72 \mathrm{~h}$ (Figure 4 ).

The time intervals also affected the mortality of the nymphs. After $36 \mathrm{~h}$ of treatment, the mortality range of the isolates was between 25.33 to $32 \%$. The mortality was 48.95 to $58.60 \%$ after 48 h, 56.66 to $68.54 \%$ after $60 \mathrm{~h}$, and 59.99 to $75.70 \%$ after $72 \mathrm{~h}$ of treatment with the same concentration $\left(1 \times 10^{8}\right.$ conidia $\left.\mathrm{mL}^{-1}\right)$ of the conidia suspension. T. harzianum (TMS623) caused the highest mortality of $75.70 \%$, followed by T. harzianum (TMS114), which caused $70.00 \%$ mortality after $72 \mathrm{~h}$ treatment. However, the isolates TMS321, TMS45, TMS633, TMS628, and TMS707 caused 59.33 to $67.85 \%$ mortality. Significantly higher nymph mortality was found for T. harzianum (TMS623) compared to other isolates (Figure 4).

\subsubsection{Efficacy Evaluation against Adults}

Data that were obtained from bioassay experiments that were treated with four different concentrations of the conidia suspension showed that no mortality within one day in the treatments and up to two days in the controls. All of the isolates showed different mortality of adults up to six days of treatment (Figure 5).

Different mortality was observed in different concentrations of the conidia suspension. The highest mortality range of the isolates was found from 57.45 to $72.31 \%$ in $1 \times 10^{8}$ conidia $\mathrm{mL}^{-1}(F=300.93, p<0.001)$, while 33.79 to $42.44 \%$ mortality was found 
in $1 \times 10^{5}$ conidia $\mathrm{mL}^{-1}(F=47.62, p<0.001)$ within the same six-day treatment period (Figure 5).

The mortality was also dependent on the duration of the application of conidia suspension. The mortality was 8 to $13.33 \%$ after two days, 20.80 to $28.17 \%$ after three days, 37.25 to $50.35 \%$ after four days, 53.85 to $66.44 \%$ after five days, and 57.45 to $72.31 \%$ after six days with the same concentration of $1 \times 10^{8}$ conidia $\mathrm{mL}^{-1}$. The highest adult mortality of $72.31 \%$ was found after six days of treatment in $1 \times 10^{8}$ conidia $\mathrm{mL}^{-1}$ suspension of T. harzianum (TMS623), followed by T. harzianum (TMS114) which caused $68.00 \%$ mortality. At the same time, other isolates of TMS321, TMS45, TMS633, TMS628, and TMS707 caused 57.45 to $65.24 \%$ mortality. Adult mortality was also significantly higher for T. harzianum (TMS623) than for other isolates (Figure 5).

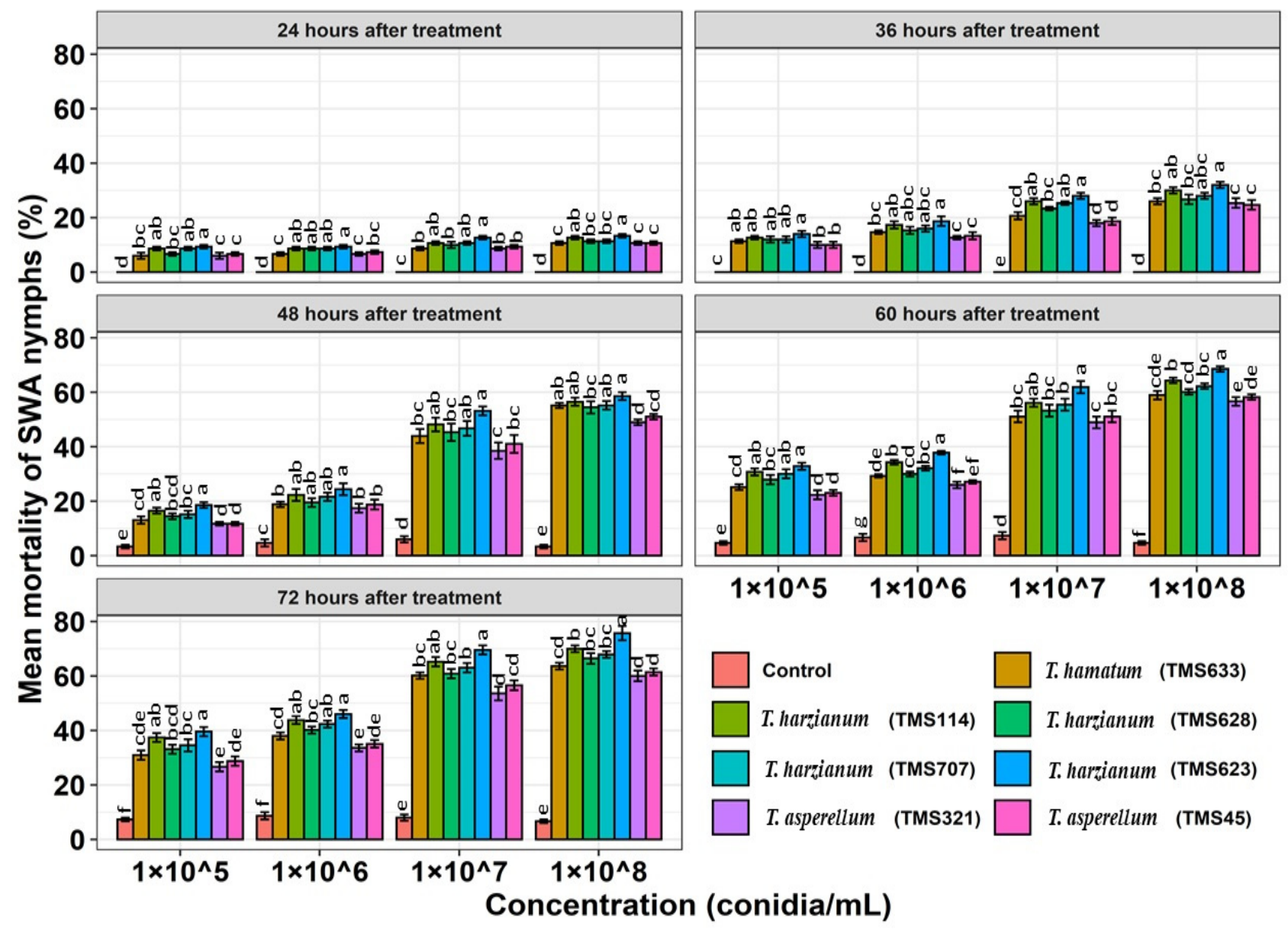

Figure 4. The efficacy of seven Trichoderma isolates against C. lanigera nymphs that were treated with four different concentrations $\left(1 \times 10^{5}, 1 \times 10^{6}, 1 \times 10^{7}\right.$, and $1 \times 10^{8}$ conidia $\left.\mathrm{mL}^{-1}\right)$ of conidia suspension up to $72 \mathrm{~h}$ treatment. Different letters indicate significant differences $(p \leq 0.05)$ among the treatments. The columns represent the mean \pm SEM $(n=3)$. SEM = standard error mean.

\subsection{Lethal Concentrations and Lethal Times for Isolates against C. lanigera}

Lethal concentrations ( $\left.\mathrm{LC}_{50} \& \mathrm{LC}_{90}\right)$ and lethal times $\left(\mathrm{LT}_{50} \& \mathrm{LT}_{90}\right)$ values were measured for the efficacy of the isolates for the mortality of the nymphs and adults of C. lanigera.

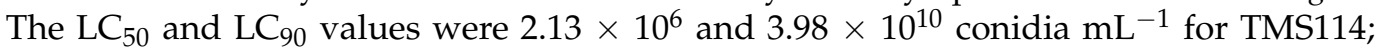
$3.31 \times 10^{6}$ and $5.24 \times 10^{10}$ conidia $\mathrm{mL}^{-1}$ for TMS628; $2.51 \times 10^{6}$ and $5.01 \times 10^{10}$ conidia $\mathrm{mL}^{-1}$ for TMS707; $8.31 \times 10^{6}$ and $1.38 \times 10^{11}$ conidia $\mathrm{mL}^{-1}$ for TMS45; $1.47 \times 10^{7}$

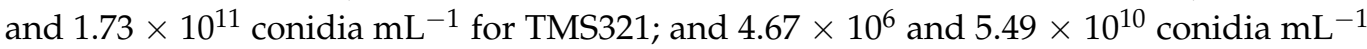
for TMS633 for nymph mortality. The lowest LC $_{50}$ and LC $_{90}$ values of $6.30 \times 10^{5}$ and $3.01 \times 10^{9}$ conidia $\mathrm{mL}^{-1}$ were found for T. harzianum (TMS623) (Table 2). 
On the other hand, for the mortality of the adults, the $\mathrm{LC}_{50}$ and $\mathrm{LC}_{90}$ values were $1.20 \times 10^{6}$ and $1.14 \times 10^{11}$ conidia $\mathrm{mL}^{-1}$ for TMS114; $2.95 \times 10^{6}$ and $7.94 \times 10^{11}$ conidia $\mathrm{mL}^{-1}$ for TMS628; $1.90 \times 10^{6}$ and $3.89 \times 10^{11}$ conidia $\mathrm{mL}^{-1}$ for TMS707; $6.30 \times 10^{6}$ and

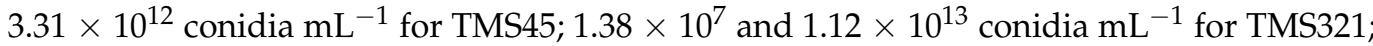
and $5.12 \times 10^{6}$ and $3.16 \times 10^{12}$ conidia $\mathrm{mL}^{-1}$ for TMS633. The lowest $\mathrm{LC}_{50}$ and $\mathrm{LC}_{90}$ values of $6.16 \times 10^{5}$ and $2.23 \times 10^{10}$ conidia $\mathrm{mL}^{-1}$ were found for T. harzianum (TMS623) (Table 3).

Consequently, for the adult's mortality, the $\mathrm{LT}_{50}$ and $\mathrm{LT}_{90}$ values for TMS114, TMS628, TMS70, TMS45, TMS321, and TMS633 were 4.26 and 9.54 days, 4.57 and 10.71 days, 4.36 and 10.00 days, 4.89 and 12.30 days, 5.05 and 12.58 days, and 4.78 and 11.22 days, respectively. The lowest $\mathrm{LT}_{50}$ and $\mathrm{LT}_{90}$ values of 3.98 and 8.70 days were found for T. harzianum (TMS623) (Table 5).

The $\mathrm{LT}_{50}$ and $\mathrm{LT}_{90}$ values for TMS114, TMS628, TMS70, TMS45, TMS321, and TMS633 were $47.86 \& 107.15$ h; $51.28 \& 117.48$ h; $50.11 \& 112.20$ h; $53.70 \& 125.89$ h; $54.95 \& 134.89 \mathrm{~h}$ and 52.48; and $120.22 \mathrm{~h}$, respectively, for nymph mortality. The lowest $\mathrm{LT}_{50}$ and $\mathrm{LT}_{90}$ values of 42.65 \& $93.32 \mathrm{~h}$ were found for T. harzianum (TMS623) (Table 4).

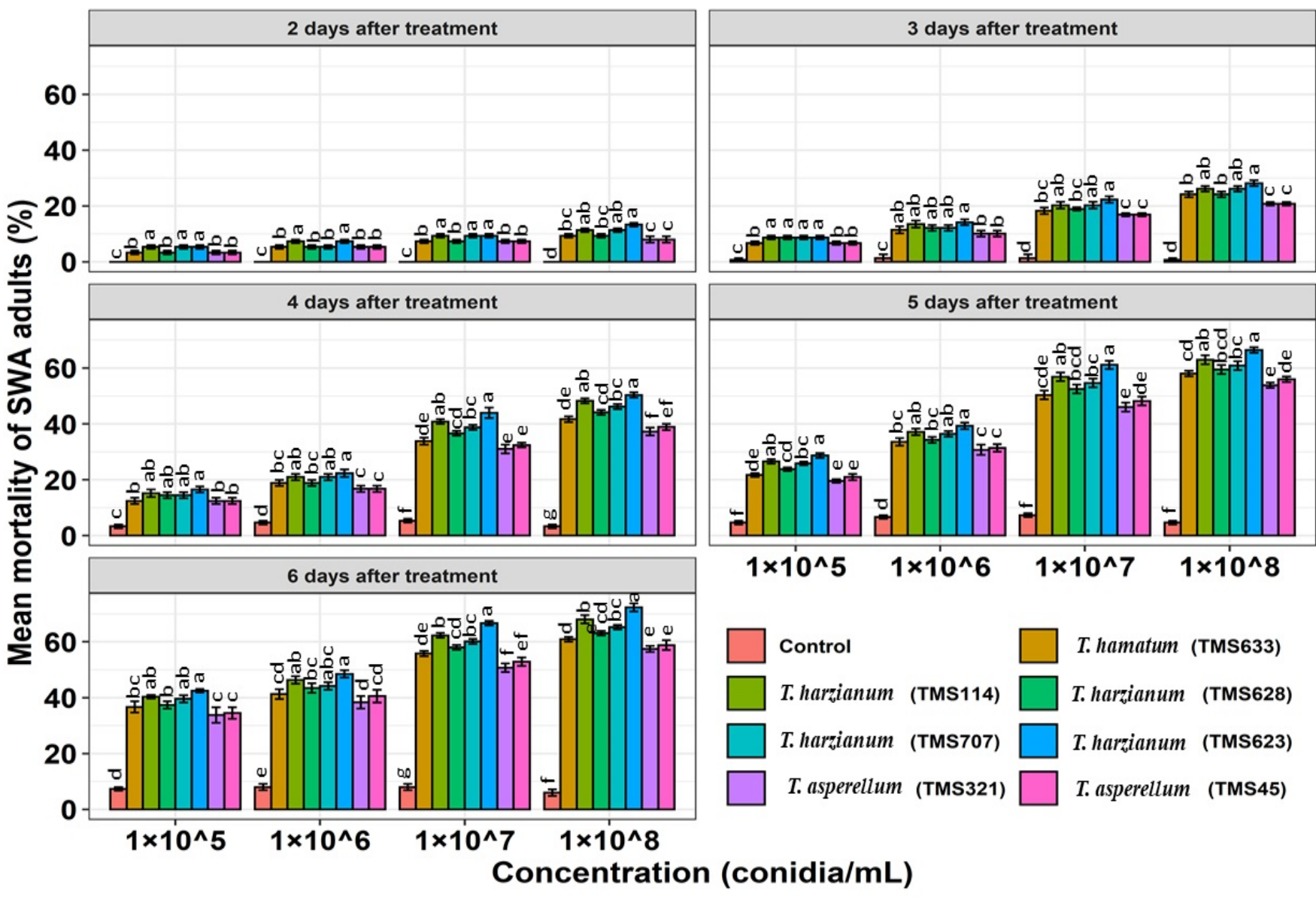

Figure 5. The efficacy of seven Trichoderma isolates against $C$. lanigera adults that were treated with

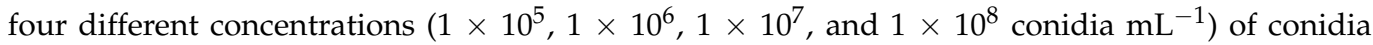
suspension up to six days treatment. The different letters indicate significant differences $(p \leq 0.05)$ among the treatments. The columns represent the mean $\pm \operatorname{SEM}(n=3)$. SEM = standard error mean. 
Table 2. $\mathrm{LC}_{50} \& \mathrm{LC}_{90}$ values for the efficacy of isolates against nymphs using different concentrations $\left(1 \times 10^{5}\right.$ to $\left.1 \times 10^{8} \mathrm{conidia}^{-1}\right) \mathrm{m}^{-1}$ conidia suspension after $72 \mathrm{~h}$ treatment.

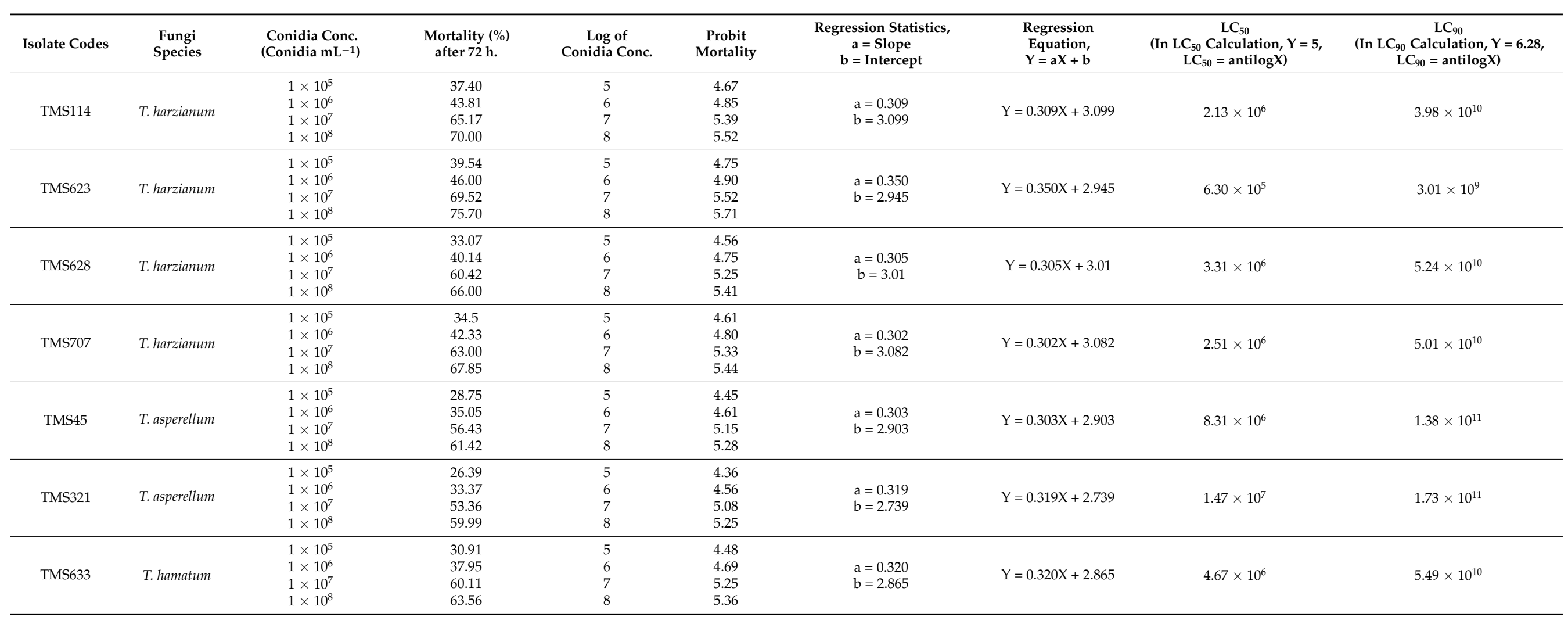




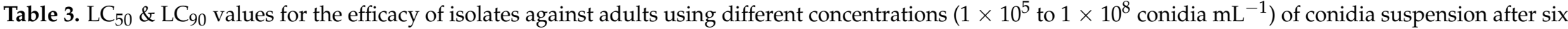
days treatment.

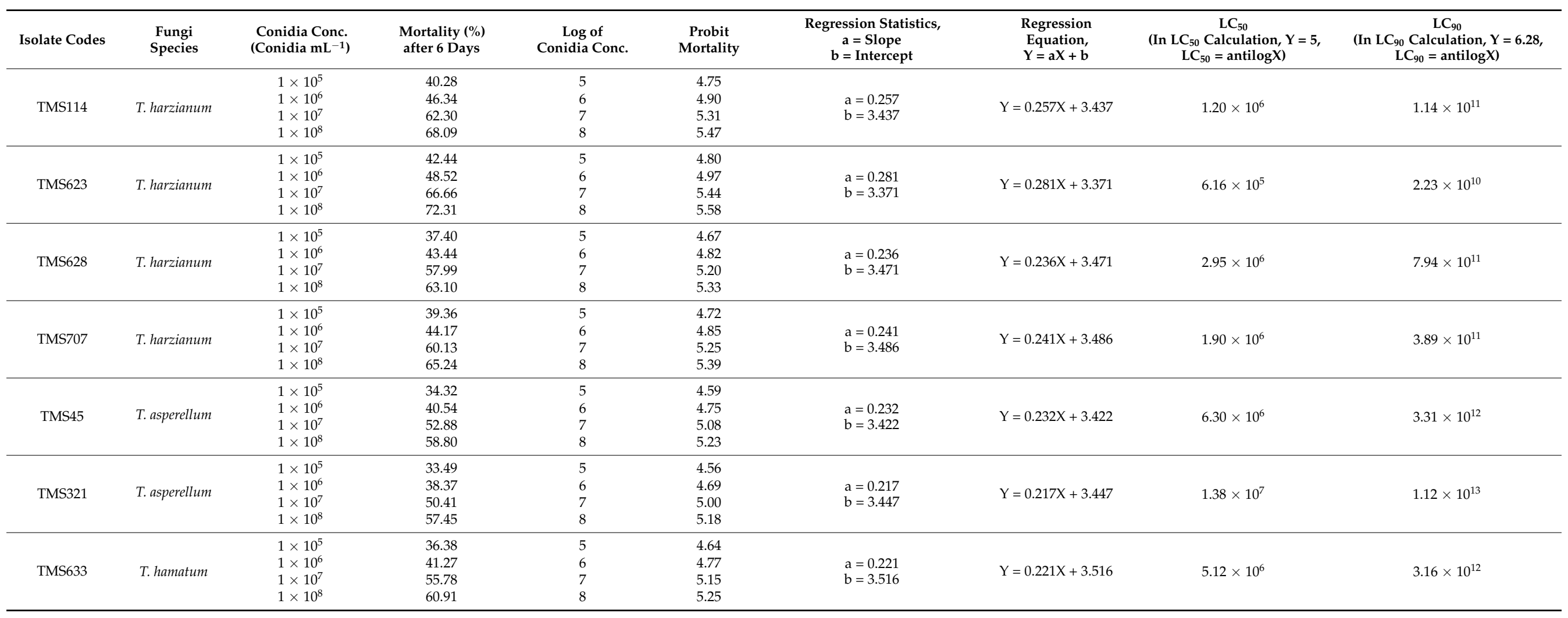


Table 4. $\mathrm{LT}_{50} \& \mathrm{LT}_{90}$ values for the efficacy of isolates against nymphs using mortality of different times ( 24 to $\left.72 \mathrm{~h}\right)$ at $1 \times 10^{8}$ conidia $\mathrm{mL}^{-1}$ suspension.

\begin{tabular}{|c|c|c|c|c|c|c|c|c|c|}
\hline Isolate Codes & $\begin{array}{l}\text { Fungi } \\
\text { Species }\end{array}$ & $\begin{array}{l}\text { Mortality Time } \\
\text { (h) }\end{array}$ & Mortality (\%) & $\begin{array}{l}\text { Log of } \\
\text { Mortality Time } \\
\text { (h) }\end{array}$ & $\begin{array}{c}\text { Probit } \\
\text { Mortality }\end{array}$ & $\begin{array}{c}\text { Regression Statistics, } \\
\mathbf{a}=\text { Slope } \\
\mathbf{b}=\text { Intercept }\end{array}$ & $\begin{array}{l}\text { Regression Equation, } \\
\qquad=a X+b\end{array}$ & $\begin{array}{c}\mathrm{LT}_{50} \\
\left(\text { In } \mathrm{LT}_{50} \text { Calculation, } \mathrm{Y}=5\right. \\
\mathrm{LT}_{50}=\text { antilogX)(h) }\end{array}$ & $\begin{array}{c}\mathrm{LT}_{90} \\
\left(\mathrm{In}_{\mathrm{LT}} \mathrm{LT}_{90} \text { Calculation, } \mathrm{Y}=6.28,\right. \\
\mathrm{LT}_{90}=\text { antilogX) }(\mathrm{h})\end{array}$ \\
\hline TMS114 & T. harzianum & $\begin{array}{l}24 \\
36 \\
48 \\
60 \\
72\end{array}$ & $\begin{array}{l}12.33 \\
30.00 \\
56.43 \\
64.34 \\
70.00\end{array}$ & $\begin{array}{l}1.38 \\
1.56 \\
1.68 \\
1.78 \\
1.86\end{array}$ & $\begin{array}{l}3.82 \\
4.48 \\
5.15 \\
5.36 \\
5.52\end{array}$ & $\begin{array}{c}a=3.706 \\
b=-1.252\end{array}$ & $Y=3.706 X-1.252$ & 47.86 & 107.15 \\
\hline TMS623 & T. harzianum & $\begin{array}{l}24 \\
36 \\
48 \\
60 \\
72 \\
\end{array}$ & $\begin{array}{l}13.33 \\
32.00 \\
58.60 \\
68.54 \\
75.70\end{array}$ & $\begin{array}{l}1.38 \\
1.56 \\
1.68 \\
1.78 \\
1.86\end{array}$ & $\begin{array}{c}3.87 \\
4.53 \\
5.23 \\
5.5 \\
5.71\end{array}$ & $\begin{array}{c}\mathrm{a}=3.997 \\
\mathrm{~b}=-1.630\end{array}$ & $Y=3.997 X-1.630$ & 42.65 & 93.32 \\
\hline TMS628 & T. harzianum & $\begin{array}{l}24 \\
36 \\
48 \\
60 \\
72 \\
\end{array}$ & $\begin{array}{l}11.33 \\
26.33 \\
54.46 \\
60.15 \\
66.42 \\
\end{array}$ & $\begin{array}{l}1.38 \\
1.56 \\
1.68 \\
1.78 \\
1.86 \\
\end{array}$ & $\begin{array}{c}3.77 \\
4.36 \\
5.1 \\
5.25 \\
5.41 \\
\end{array}$ & $\begin{array}{c}\mathrm{a}=3.611 \\
\mathrm{~b}=-1.183\end{array}$ & $Y=3.611 X-1.183$ & 51.28 & 117.48 \\
\hline TMS707 & T. harzianum & $\begin{array}{l}24 \\
36 \\
48 \\
60 \\
72 \\
\end{array}$ & $\begin{array}{l}11.33 \\
28.00 \\
55.76 \\
62.25 \\
67.85 \\
\end{array}$ & $\begin{array}{l}1.38 \\
1.56 \\
1.68 \\
1.78 \\
1.86 \\
\end{array}$ & $\begin{array}{l}3.77 \\
4.42 \\
5.15 \\
5.31 \\
5.44 \\
\end{array}$ & $\begin{array}{c}\mathrm{a}=3.680 \\
\mathrm{~b}=-1.256\end{array}$ & $Y=3.680 X-1.256$ & 50.11 & 112.20 \\
\hline TMS45 & T. asperellum & $\begin{array}{l}24 \\
36 \\
48 \\
60 \\
72 \\
\end{array}$ & $\begin{array}{l}10.00 \\
24.46 \\
51.02 \\
58.21 \\
61.42 \\
\end{array}$ & $\begin{array}{l}1.38 \\
1.56 \\
1.68 \\
1.78 \\
1.86 \\
\end{array}$ & $\begin{array}{c}3.72 \\
4.29 \\
5.03 \\
5.2 \\
5.25 \\
\end{array}$ & $\begin{array}{c}\mathrm{a}=3.460 \\
\mathrm{~b}=-1.014\end{array}$ & $Y=3.460 X-1.014$ & 53.70 & 125.89 \\
\hline TMS321 & T. asperellum & $\begin{array}{l}24 \\
36 \\
48 \\
60 \\
72 \\
\end{array}$ & $\begin{array}{l}10.00 \\
25.33 \\
48.45 \\
56.36 \\
59.99 \\
\end{array}$ & $\begin{array}{l}1.38 \\
1.56 \\
1.68 \\
1.78 \\
1.86 \\
\end{array}$ & $\begin{array}{l}3.72 \\
4.33 \\
4.95 \\
5.15 \\
5.25 \\
\end{array}$ & $\begin{array}{c}a=3.371 \\
b=-0.885\end{array}$ & $Y=3.371 X-0.885$ & 54.95 & 134.89 \\
\hline TMS633 & T. hamatum & $\begin{array}{l}24 \\
36 \\
48 \\
60 \\
72\end{array}$ & $\begin{array}{l}10.00 \\
26.00 \\
55.16 \\
58.92 \\
63.56\end{array}$ & $\begin{array}{l}1.38 \\
1.56 \\
1.68 \\
1.78 \\
1.86\end{array}$ & $\begin{array}{l}3.72 \\
4.36 \\
5.13 \\
5.23 \\
5.36\end{array}$ & $\begin{array}{c}\mathrm{a}=3.622 \\
\mathrm{~b}=-1.219\end{array}$ & $Y=3.622 X-1.219$ & 52.48 & 120.22 \\
\hline
\end{tabular}


Table 5. $\mathrm{LT}_{50} \& \mathrm{LT}_{90}$ values for the efficacy of isolates against adults using mortality of different times (two to six days) at $1 \times 10^{8}$ conidia $\mathrm{mL}^{-1}$ suspension .

\begin{tabular}{|c|c|c|c|c|c|c|c|c|c|}
\hline Isolate Codes & $\begin{array}{l}\text { Fungi } \\
\text { Species }\end{array}$ & $\begin{array}{l}\text { Mortality Time } \\
\text { (day) }\end{array}$ & Mortality (\%) & $\begin{array}{l}\text { Log of } \\
\text { Mortality Time } \\
\text { (day) }\end{array}$ & Probit Mortality & $\begin{array}{c}\text { Regression Statistics, } \\
\mathbf{a}=\text { Slope } \\
\mathbf{b}=\text { Intercept }\end{array}$ & $\begin{array}{c}\text { Regression } \\
\text { Equation, } \\
\mathrm{Y}=\mathrm{aX}+\mathrm{b}\end{array}$ & $\begin{array}{c}\mathrm{LT}_{50} \\
\left(\mathrm{In} \mathrm{LT}_{50} \text { Calculation, } \mathrm{Y}=5\right. \\
\mathrm{LT}_{50}=\text { antilogX) (day) }\end{array}$ & $\begin{array}{c}\mathrm{LT}_{90} \\
\text { (In } \mathrm{LT}_{90} \text { Calculation, } \mathrm{Y}=6.28, \\
\mathrm{LT}_{90}=\text { antilogX) (day) }\end{array}$ \\
\hline \multirow{5}{*}{ TMS114 } & \multirow{5}{*}{ T. harzianum } & 2 & 11.33 & 0.30 & 3.77 & \multirow{5}{*}{$\begin{array}{l}\mathrm{a}=3.709 \\
\mathrm{~b}=2.641\end{array}$} & \multirow{5}{*}{$\mathrm{Y}=3.709 \mathrm{X}+2.641$} & \multirow{5}{*}{4.26} & \multirow{5}{*}{9.54} \\
\hline & & 3 & 26.16 & 0.48 & 4.36 & & & & \\
\hline & & 4 & 46.21 & 0.60 & 4.9 & & & & \\
\hline & & 5 & 62.36 & 0.70 & 5.31 & & & & \\
\hline & & 6 & 68.09 & 0.78 & 5.47 & & & & \\
\hline \multirow{4}{*}{ TMS623 } & \multirow{4}{*}{ T. harzianum } & 2 & 13.33 & 0.30 & 3.87 & \multirow{4}{*}{$\begin{array}{l}\mathrm{a}=3.778 \\
\mathrm{~b}=2.702\end{array}$} & \multirow{4}{*}{$Y=3.778 X+2.702$} & \multirow{4}{*}{3.98} & \multirow{4}{*}{8.70} \\
\hline & & 3 & 28.17 & 0.48 & 4.42 & & & & \\
\hline & & 4 & 50.35 & 0.60 & 5.00 & & & & \\
\hline & & 5 & 66.54 & 0.70 & 5.44 & & & & \\
\hline \multirow{5}{*}{ TMS628 } & \multirow{5}{*}{ T. harzianum } & 2 & 9.33 & 0.30 & 3.66 & \multirow{5}{*}{$\begin{array}{l}a=3.679 \\
b=2.569\end{array}$} & \multirow{5}{*}{$Y=3.679 X+2.569$} & \multirow{5}{*}{4.57} & \multirow{5}{*}{10.71} \\
\hline & & 3 & 24.15 & 0.48 & 4.29 & & & & \\
\hline & & 4 & 44.14 & 0.60 & 4.85 & & & & \\
\hline & & 5 & 59.45 & 0.70 & 5.23 & & & & \\
\hline & & 6 & 63.10 & 0.78 & 5.33 & & & & \\
\hline \multirow{5}{*}{ TMS707 } & \multirow{5}{*}{ T. harzianum } & 2 & 11.33 & 0.30 & 3.77 & \multirow{5}{*}{$\begin{array}{l}\mathrm{a}=3.539 \\
\mathrm{~b}=2.711\end{array}$} & \multirow{5}{*}{$Y=3.539 X+2.711$} & \multirow{5}{*}{4.36} & \multirow{5}{*}{10.00} \\
\hline & & 3 & 26.16 & 0.48 & 4.36 & & & & \\
\hline & & 4 & 46.21 & 0.60 & 4.90 & & & & \\
\hline & & 5 & 60.35 & 0.70 & 5.25 & & & & \\
\hline & & 6 & 65.24 & 0.78 & 5.39 & & & & \\
\hline \multirow{4}{*}{ TMS45 } & \multirow{4}{*}{ T. asperellum } & 2 & 8.00 & 0.30 & 3.59 & & & & \\
\hline & & 4 & 38.91 & 0.60 & 4.72 & $\begin{array}{l}a=3.653 \\
b=2.481\end{array}$ & $Y=3.653 X+2.481$ & 4.89 & 12.30 \\
\hline & & 5 & 55.96 & 0.70 & 5.15 & $\mathrm{~b}=2.481$ & & & \\
\hline & & 6 & 58.80 & 0.78 & 5.23 & & & & \\
\hline & & 2 & 8.00 & 0.30 & 3.59 & & & & \\
\hline & & 3 & 20.00 & 0.48 & 4.16 & & & & \\
\hline TMS321 & T. asperellum & 4 & 37.25 & 0.60 & 4.67 & $\begin{array}{l}a=3.507 \\
b=2531\end{array}$ & $Y=3.507 X+2.531$ & 5.05 & 12.58 \\
\hline & & 5 & 53.35 & 0.70 & 5.08 & $\mathrm{~b}=2.531$ & & & \\
\hline & & 6 & 57.45 & 0.78 & 5.18 & & & & \\
\hline & & 2 & 9.33 & 0.30 & 3.66 & & & & \\
\hline & & 3 & 24.15 & 0.48 & 4.29 & & & & \\
\hline TMS633 & T. hamatum & 4 & 41.66 & 0.60 & 4.80 & $\begin{array}{l}a=3.569 \\
b=2606\end{array}$ & $Y=3.569 X+2.606$ & 4.78 & 11.22 \\
\hline & & 5 & 58.04 & 0.70 & 5.20 & $\mathrm{~b}=2.606$ & -5 & & \\
\hline & & 6 & 60.91 & 0.78 & 5.28 & & & & \\
\hline
\end{tabular}




\section{Discussion}

The fungi species of genus Trichoderma is a cosmopolitan fungus and common in all types of soil, agricultural lands, manure, decaying tissue, forest, salt marsh, desert soils, and other form of plant organic matter throughout all climatic zones [54,55]. Entomopathogenic fungi (EPFs) that infect insects are natural pathogens and they can be isolated from the soil and infected or dead insects in the field environment and used as a biological control agent [7].

In this study, T. harzianum, T. hamatum, and T. asperellum were isolated from agricultural soils by the insect bait method. However, according to previous research, the EMP fungi species, T. harzianum and T. asperelum were isolated by insect bait method [29].

In our study, the morphological identification of the Trichoderma species was performed based on the macroscopic and microscopic characteristics of the culture [35]. Molecular identification was performed using the sequence of ITS 1-5.8 S-ITS 2 regions of the rDNA with two primers, ITS 1 and ITS 4. Similarly, in some other previous studies, Trichoderma species were identified using ITS 1-5.8 S-ITS 2 regions of the rDNA with primers ITS 1 and ITS $4[29,34,56]$.

Current studies demonstrated the efficacy of different Trichoderma isolates against C. lanigera under laboratory conditions. Bioassays to determine the efficacy of conidia suspension of the isolates showed that all Trichoderma isolates that were tested were pathogenic to both nymphs and adults of $C$. lanigera, although mortality was different among the isolates (Figures 4 and 5). Similarly, Nawaz [28] reported that Trichoderma species caused $73 \%$ mortality of the aphid species, Aphis gossypii (Glover) and 53\% mortality of cotton leaf hopper (Jassid), Amrasca bigutulla bigutulla (Hemiptera: Cicadellidae) with the conidia suspension at a concentration of $1 \times 10^{8}$ conidia $\mathrm{mL}^{-1}$ after $72 \mathrm{~h}$ of treatment under laboratory condition.

Khaskheli [31] found that T. koningi (Hypocreales: Hypocreaceae), T. virens (Hypocreales: Hypocreaceae), and T. hamatum are effective fungi species for the management of gram pod borer, Helicoverpa armigera, where Trichoderma harzianum and Trichoderma gamsii (Hypocreales: Hypocreaceae) showed potential biocontrol agents against the larvae and adults of the major insect pest of Spanish vineyard, Xylotrechus arvicola (Olivier) [33].

Trichoderma harzianum has also been described as an effective biological control agent for the control of the cabbage aphid, Brevicoryne brassicae which caused $70 \%$ mortality after $72 \mathrm{~h}$ of treatment [34].

Mukherjee [29] conducted an experiment for the biological control of the papaya aphid, Aphis gossypii (Glover) using conidia suspension of different entomopathogenic fungi at a concentration $1 \times 10^{7}$ conidia $\mathrm{mL}^{-1}$. Entomopathogenic fungi, Trichoderma harzianum, Penicillum sp., Paecilomyces lilacinus, Fusarium sp., and Aspergillus heteromorphous (Eurotiales: Trichocomaceae) caused 50\%, 40-70\%, 50\%, 60\%, and 50\% mortality, respectively, after $48 \mathrm{~h}$ of treatment.

The virulence potential of entomopathogenic fungi against target aphid populations varies for different isolates and also varies from strain to strain. Similar aphid species can have varying levels of susceptibility to different types of fungal strain [57].

In the current study, the efficacy results of seven isolates belonged to three species of T. harzianum, T. hamatum, and T. asperellum with four different conidia concentrations $\left(1 \times 10^{5}, 1 \times 10^{6}, 1 \times 10^{7}\right.$, and $1 \times 10^{8}$ conidia $\left.\mathrm{mL}^{-1}\right)$ showed that the mortality of both nymphs and adults are dependent on concentration and time. The mortality increased with increasing conidia concentration and exposure time. The maximum nymph and adult mortality due to Trichoderma isolates was higher with the higher concentrations $\left(1 \times 10^{8}\right.$ conidia $\left.\mathrm{mL}^{-1}\right)$ of the conidia suspension whereas the mortality was lower at a lower concentration $\left(1 \times 10^{5}\right.$ conidia $\left.\mathrm{mL}^{-1}\right)$ within the same treatment period of $72 \mathrm{~h}$ and 6 days (Figures 4 and 5). This indicates that the mortality is effectively controlled by the density of the conidia suspension. More and more mycelium and conidia grow with a higher density of conidia. This statement is strongly consistent with Nasution [30] who stated that a higher density of conidia increases the presence of conidia in the contact with 
the insect's body, giving the conidia a better chance to stick, germinate, and penetrate into the insect's body.

In addition, several other previous studies on the concentrations of conidia of Beauveria bassiana, Paecilomyces fumosoroseus, Metarhizium anisopliae, and Verticillium lecanii (Hypocreales: Cordycipitaceae) against various species of aphids, plant bugs, Lygus lineolaris (Hemiptera: Miridae), blowfly, Lucilia sericata (Diptera: Calliphoridae), and june beetle, Hoplia philanthus, (Coleoptera: Scarabaeidae) have shown that mortality increases with increasing concentrations of conidia suspension and time of exposure [57-60].

As an alternative, the maximum mortality was found for nymphs and adults with a maximum treatment period of $72 \mathrm{~h}$ and 6 days with the same conidia concentration $\left(1 \times 10^{8}\right.$ conidia $\left.\mathrm{mL}^{-1}\right)$ (Figures 4 and 5$)$. This indicates that the longer the EPFs remain in the insect body, the more the mortality increases. The damage to the body tissues of insects from fungal infections will be more severe so the mortality rate will be higher. The previous researcher [30] also reported that the longer the contact time between EPFs and host, the more EPFs can infect the host, leading to increase insect mortality.

Lethal concentration (LC) and lethal time (LT) are a yard measure which can be used to determine the efficacy of a pathogen in relation to the concentration of the suspension of conidia and the time it takes for killing the insect that is exposed at a certain concentration. In our study, $\mathrm{LC}_{50}$ and $\mathrm{LC}_{90}$ values as well as $\mathrm{LT}_{50}$ and $\mathrm{LT}_{90}$ values were determined for the efficacy of the isolates for the mortality of nymphs and adults of $C$. lanigera. Among the seven isolates, T. harzianum (TMS623) showed lower LC and LT values compared to other isolates (Tables 2 to 5). Similarly, $\mathrm{LC}_{50}$ values from $1.15 \times 10^{6}$ to $6.76 \times 10^{6}$ conidia $\mathrm{mL}^{-1}$ were found for the entomopathogenic fungus, B. bassiana against four aphid species, Brevicoryne brassicae, Schizaphis graminum, Lipaphis erysimi (Hemiptera: Aphididae), and Rhopalosiphum maidis (Hemiptera: Aphididae) [57]. In another previous study, an $\mathrm{LC}_{50}$ value of $6.75 \times 10^{6}$ conidia $\mathrm{mL}^{-1}$ was found for A. flavus (Eurotiales:Trichocomaceae) against seed bug, Elasmolomus pallens (Dallas) (Hemiptera: Rhyparochromidae) [47]. An $\mathrm{LT}_{50}$ value of 5.54 days was found against Aphis craccivora (Hemiptera: Aphididae) due to entomopathogenic fungi, M. anisopliae [61]. According to Mweke [62], the $\mathrm{LT}_{50}$ values range of the 23 isolates of M. anisopliae, B. bassiana, and Isaria spp. (Hypocreales: Cordycipitaceae) against Aphis craccivora was found from 3.3 to 6.3 days.

According to $\mathrm{LC}_{50}$ and $\mathrm{LT}_{50}$ values of $T$. harzianum (TMS623) indicated that it has the potential candidate against sugarcane woolly aphid, C. lanigera compared to other isolates that were tested in this study.

\section{Conclusions}

Among the seven isolates of different Trichoderma species that were tested in this study, T. harzianum (TMS623) was found to have the potential to be a biological control agent against sugarcane woolly aphid, $C$. lanigera, based on the mortality of the population that was tested. It is expected to be an alternative to chemical insecticides for the sustainable management of $C$. lanigera. As far we know, it has been reported for the first time that T. harzianum (TMS623) is a potential candidate for the biological control of $C$. lanigera and could be used as a biopesticide in agricultural crops.

Author Contributions: Conceptualization, M.S.I., V.K.S. and S.S.; investigation, M.S.I., V.K.S. and S.S.; writing—original draft preparation, M.S.I.; writing—review and editing, V.K.S. and S.S.; revisions and responses to reviewers, M.S.I. and S.S.; funding acquisition, S.S. All authors have read and agreed to the published version of the manuscript.

Funding: This research project was funded by 'Strengthening Integrated Research Facilities (SIRF)' project of Bangladesh Sugarcrop Research Institute (BSRI), Ministry of Agriculture, Bangladesh and project code number -GLA0026-2019.

Institutional Review Board Statement: Not applicable.

Informed Consent Statement: Not applicable. 
Data Availability Statement: Not applicable.

Acknowledgments: The authors would like to acknowledge the authority of Biotechnology Research Institute (BRI), Universiti Malaysia Sabah (UMS) for providing necessary research facilities.

Conflicts of Interest: The authors have declared that there is no conflicts of interest exist.

\section{References}

1. Patil, A.S.; Magar, S.B.; Shinde, V.D. Biological control of the sugarcane Woolly Aphid (Ceratovacuna lanigera) in Indian sugarcane through the release of predators. In Proceedings of the XXVI Congress, International Society of Sugar Cane Technologists (ISSCT), Durban, South Africa, 29 July-2 August 2007; pp. 797-804.

2. Patil, N.B.; Mallapur, C.P.; Sujay, Y.H. Efficacy of Acremonium zeylanicum against sugarcane wooly aphid under laboratory conditions. J. Biol. Control 2011, 25, 124-126.

3. Mukunthan, N.; Srikanth, J.; Singaravelu, B.; Asokan, S.; Kurup, N.K.; Goud, Y.S. Assessment of woolly aphid impact on growth, yield and quality parameters of sugarcane. Sugar Tech. 2008, 10, 143-149. [CrossRef]

4. Khosravi, R.; Sendi, J.J.; Zibaee, A.; Shokrgozar, M.A. Virulence of four Beauveria bassiana (Balsamo) (Asc., Hypocreales) isolates on rose sawfly, Arge rosae under laboratory condition. J. King Saud Univ. Sci. 2015, 27, 49-53. [CrossRef]

5. Roy, H.E.; Brodie, E.L.; Chandler, D.; Goettel, M.S.; Pell, J.K.; Wajnberg, E.; Vega, F.E. Deep space and hidden depths: Understanding the evolution and ecology of fungal entomopathogens. In The Ecology of Fungal Entomopathogens; Springer: Dordrecht, The Netherlands, 2009; pp. 1-6.

6. Roberts, D.W.; Humber, R.A. Entomopathogenic Fungi. In Biology of Conidial Fungi; Cole, G.T., Kendrick, B., Eds.; Academic Press: New York, NY, USA, 1981; pp. 201-236.

7. Inglis, G.D.; Goettel, M.S.; Butt, T.M.; Strasser, H. Use of hyphomycetous fungi for managing insect pests. In Fungi as Biocontrol Agents: Progress, Problems and Potential; Butt, T.M., Jackson, C.W., Magan, N., Eds.; CABI International/AAFC: Wallingford, UK, 2001; pp. 23-69.

8. Barbarin, A.M.; Jenkins, N.E.; Rajotte, E.G.; Thomas, M.B. A preliminary evaluation of the potential of Beauveria bassiana for bed bug control. J. Invertebr. Pathol. 2012, 111, 82-85. [CrossRef]

9. Wakil, W.; Schmitt, T.; Kavallieratos, N.G. Persistence and efficacy of enhanced diatomaceous earth, imidacloprid, and Beauveria bassiana against three coleopteran and one psocid stored-grain insects. Environ. Sci. Pollut. Res. 2021, 28, 23459-23472. [CrossRef]

10. Usman, M.; Wakil, W.; Piñero, J.C.; Wu, S.; Toews, M.D.; Shapiro-Ilan, D.I. Evaluation of Locally Isolated Entomopathogenic Fungi Against Multiple Life Stages of Bactrocera zonata and Bactrocera dorsalis (Diptera: Tephritidae): Laboratory and Field Study. Microorganisms 2021, 9, 1791. [CrossRef] [PubMed]

11. Gulzar, S.; Wakil, W.; Shapiro-Ilan, D. Combined Effect of Entomopathogens against Thrips tabaci Lindeman (Thysanoptera: Thripidae): Laboratory, Greenhouse and Field Trials. Insects 2021, 12, 456. [CrossRef]

12. Shah, F.A.; Wang, C.S.; Butt, T.M. Nutrition influences growth and virulence of the insect-pathogenic fungus Metarhizium anisopliae. FEMS Microbiol. Lett. 2005, 251, 259-266. [CrossRef] [PubMed]

13. Khaleil, M.M.M. Biocontrol potential of entomopathogenic fungus, Trichoderma hamatum against the cotton aphid, Aphis Gossypii. IOSR J. Environ. Sci. Toxicol. Food Technol. (IOSR-JESTFT) 2016, 10, 11-20.

14. Abdelaziz, O.; Mourad, M.S.; Oufroukh, A.; Kemal, A.B.; Karaca, I.; Kouadri, F.; Naima, B.; Bensegueni, A. Pathogenicity of three entomopathogenic fungi, to the aphid species Metopolophium dirhodum (Walker). (Homoptera: Aphididae). Egypt. J. Biol. Pest Control 2018, 28, 24. [CrossRef]

15. Dong, C.; Zhang, J.; Chen, W.; Huang, H.; Hu, Y. Characterization of a newly discovered China variety of Metarhizium anisopliae (M. anisopliae var. dcjhyium) for virulence to termites, isoenzyme, and phylogenic analysis. Microbiol. Res. 2007, $162,53-61$. [CrossRef]

16. Jung, H.S.; Lee, H.B.; Kim, K.; Lee, E.Y. Selection of Lecanicillium strains for aphid (Myzus persicae) control. Korean J. Mycol. 2006, $34,112-118$.

17. Meitkeiaski, R.T.; Pell, J.K.; Clark, S.J. Influence of pesticide use on the natural occurance of entomopathogenic fungi in arable soils in UK: Field and laboratory comparison. Biocontrol Sci. Technol. 1997, 7, 565-757.

18. Kepenekci, İ.; Yesilayer, A.; Atay, T.; Tulek, A. Pathogenicity of the entomopathogenic fungus, Purpureocillium lilacium TR1 against the Black Cherry Aphid, Myzus cerasi Fabricus (Hemiptera: Aphididae). Munis Entomol. Zool. 2014, 10, 53-60.

19. Grinyer, J.; McKay, M.; Nevalainen, H.; Herbert, B.R. Fungal proteomics: Initial mapping of biological control strain Trichoderma harzianum. Curr. Genet. 2004, 45, 163-169. [CrossRef]

20. Samuels, G.J. Trichoderma: Systematics, the sexual state, and ecology. Phytopathology 2006, 96, 195-206. [CrossRef]

21. Zhang, C.L.; Liu, S.P.; Lin, F.C.; Kubicek, C.P.; Druzhinina, I.S. Trichoderma taxi sp. nov., an endophytic fungus from Chinese yew Taxus mairei. FEMS Microbiol. Lett. 2007, 270, 90-96. [CrossRef] [PubMed]

22. Howell, C.R. Mechanisms employed by Trichoderma species in the biological control of plant diseases: The history and evolution of current concepts. Plant Dis. 2003, 87, 4-10. [CrossRef]

23. Küçük, Ç.; Kivanç, M. Isolation of Trichoderma spp. and determination of their antifungal, biochemical and physiological features. Turk. J. Biol. 2004, 27, 247-253. 
24. Chaverri, P.; Castlebury, L.A.; Overton, B.E.; Samuels, G.J. Hypocrea/Trichoderma: Species with conidiophore elongations and green conidia. Mycologia 2003, 95, 1100-1140. [CrossRef]

25. Rey, M.; Delgado-Jarana, J.; Benitez, T. Improved antifungal activity of a mutant of Trichoderma harzianum CECT 2413 which produces more extracellular proteins. Appl. Microbiol. Biotechnol. 2001, 55, 604-608. [CrossRef]

26. Lu, B.; Druzhinina, I.S.; Fallah, P.; Chaverri, P.; Gradinger, C.; Kubicek, C.P.; Samuels, G.J. Hypocrea/Trichoderma species with pachybasium-like conidiophores: Teleomorphs for T. minutisporum and T. polysporum and their newly discovered rela-tives. Mycologia 2004, 96, 310-342. [CrossRef]

27. Weindling, R. Trichoderma lignorum as a parasite of other soil fungi. Phytopathology 1932, 22, 837-845.

28. Nawaz, A.; Gogi, M.D.; Naveed, M.; Arshad, M.; Sufyan, M.; Binyameen, M.; Islam, S.U.; Waseem, M.; Ayyub, M.B.; Arif, M.J.; et al. In vivo and in vitro assessment of Trichoderma species and Bacillus thuringiensis integration to mitigate insect pests of brinjal (Solanum melongena L.). Egypt. J. Biol. Pest Control 2020, 30, 60. [CrossRef]

29. Mukherjee, A.; Debnath, P.; Ghosh, S.K.; Medda, P.K. Biological control of papaya aphid (Aphis gossypii Glover) using entomopathogenic fungi. Vegetos 2020, 33, 1-10. [CrossRef]

30. Nasution, L.; Corah, R.; Nuraida, N.; Siregar, A.Z. Effectiveness Trichoderma and Beauveria bassiana on Larvae of Oryctes rhinoceros On Palm Oil Plant (Elaeis Guineensis Jacq.) In Vitro. Int. J. Environ. Agric. Biotechnol. 2018, 3, 239050. [CrossRef]

31. Khaskheli, X.C.; Gong, G.; Poussio, G.B.; Otho, S.A. The use of promising entomopathogenic fungi for eco-friendly man-agement of Helicoverpa armigera Hubner in chickpea. Int. J. Environ. Agric. Biotechnol. 2019, 4, 704-712.

32. Ganassi, S.; Moretti, A.; Stornelli, C.; Fratello, B.; Pagliai, A.B.; Logrieco, A.; Sabatini, M.A. Effect of Fusarium, Paecilomyces and Trichoderma formulations against aphid Schizaphis graminum. Mycopathologia 2001, 151, 131-138. [CrossRef]

33. Rodríguez-González, Á.; Carro-Huerga, G.; Mayo-Prieto, S.; Lorenzana, A.; Gutiérrez, S.; Peláez, H.J.; Casquero, P.A. Investigations of Trichoderma spp. and Beauveria bassiana as biological control agent for Xylotrechus arvicola, a major insect pest in Spanish vineyards. J. Econ. Entomol. 2018, 111, 2585-2591. [CrossRef] [PubMed]

34. Pacheco, J.C.; Poltronieri, A.S.; Porsani, M.V.; Zawadneak, M.A.C.; Pimentel, I.C. Entomopathogenic potential of fungi isolated from intertidal environments against the cabbage aphid Brevicoryne brassicae (Hemiptera: Aphididae). Biocontrol Sci. Technol. 2017, 27, 496-509. [CrossRef]

35. Siddiquee, S. Practical Handbook of the Biology and Molecular Diversity of Trichoderma Species from Tropical Regions; Springer International Publishing: Cham, Swizerland, 2017; pp. 22-23.

36. Zimmermann, G. The 'Galleria bait method' for detection of entomopathogenic fungi in soil. J. Appl. Entomol. 1986, 102, 213-215. [CrossRef]

37. Hasyim, A. Patogenisitas Isolat Beauveria bassiana (Balsamo) Vuillemin dalam Mengendalikan Hama Penggerek Bonggol Pisang, Cosmopolites sordidus Germar. J. Horti. 2003, 13, 120-130.

38. Zimmerman, G. Suggestions for a standardised method for reisolation of entomopathogenic fungi from soil using the bait method (G. Zimmermann, J. Appl. Ent. 102,213-215, 1986). IOBC/WPRS Bull. Insect Pathog. Insect Parasit. Nematodes 1998, $21,289$.

39. Inglis, G.D.; Enkerli, J.; Goettel, M.S. Laboratory techniques used for entomopathogenic fungi: Hypocreales. Man. Tech. Invertebr. Pathol. 2012, 2, 18-53.

40. Cubero, O.F.; Crespo, A.N.A.; Fatehi, J.; Bridge, P.D. DNA extraction and PCR amplification method suitable for fresh, herbariumstored, lichenized, and other fungi. Plant Syst. Evol. 1999, 216, 243-249. [CrossRef]

41. White, T.J.; Bruns, T.; Lee, S.; Taylor, J.W. Amplification and direct sequencing of fungal ribosomal RNA genes for phylogenetics. PCR Protoc. A Guide Methods Appl. 1990, 18, 315-322.

42. Castillo, M.G.; Rivera, I.A.; Padilla, A.B.; Lara, F.; Victoriano, C.N.; Herrera, R.R. Isolation and identification of novel entomopathogenic fungal strains of the Beauveria and Metarhizium generous. BioTechnol. Indian J. 2012, 6, 386-395.

43. Sneath, P.H.A.; Sokal, R.R. Numerical Taxonomy; Freeman: San Francisco, LA, USA, 1973.

44. Kumar, S.; Stecher, G.; Li, M.; Knyaz, C.; Tamura, K. MEGA X: Molecular Evolutionary Genetics Analysis across computing platforms. Mol. Biol. Evol. 2018, 35, 1547-1549. [CrossRef]

45. Kimura, M. A simple method for estimating evolutionary rate of base substitutions through comparative studies of nucleotide sequences. J. Mol. Evol. 1980, 16, 111-120. [CrossRef] [PubMed]

46. Javed, K.; Javed, H.; Mukhtar, T.; Qiu, D. Efficacy of Beauveria bassiana and Verticillium lecanii for the management of whitefly and aphid. Pak. J. Agric. Sci. 2019, 56, 669-674.

47. Umaru, F.F.; Simarani, K. Evaluation of the Potential of Fungal Biopesticides for the Biological Control of the Seed Bug, Elasmolomus pallens (Dallas) (Hemiptera: Rhyparochromidae). Insects 2020, 11, 277. [CrossRef] [PubMed]

48. Herlinda, S. Spore density and viability of entomopathogenic fungal isolates from Indonesia, and their virulence against Aphis gossypii Glover (Homoptera: Aphididae). Trop. Life Sci. Res. 2010, 21, 11.

49. Ujjan, A.A.; Shahzad, S. Use of entomopathogenic fungi for the control of mustard aphid (Lipaphis erysimi) on canola (Brassica napus L.). Pak. J. Bot. 2012, 44, 2081-2086.

50. Shrestha, G.; Enkegaard, A.; Steenberg, T. Laboratory and semi-field evaluation of Beauveria bassiana (Ascomycota: Hypocreales) against the lettuce aphid, Nasonovia ribisnigri (Hemiptera: Aphididae). Biol. Control. 2015, 85, 37-45. [CrossRef]

51. Shi, W.B.; Feng, M.G. Lethal effect of Beauveria bassiana, Metarhizium anisopliae, and Paecilomyces fumosoroseus on the eggs of Tetranychus cinnabarinus (Acari: Tetranychidae) with a description of a mite egg bioassay system. Biol. Control. 2004, 30, 165-173. [CrossRef] 
52. Abbott, W.S. A method of computing the effectiveness of an insecticide. J. Econ. Entomol. 1925, 18, 265-267. [CrossRef]

53. Finney, D.J. Probit Analysis; Cambridge University Press: Cambridge, UK, 1952.

54. Gams, W.; Bissett, J. Morphology and identification of Trichoderma. In Trichoderma and Gliocladium; Basic Biology, Taxonomy and Genetics; Kubicek, C.P., Harman, G.E., Eds.; Taylors and Francies Ltd.: London, UK, 1998; Volume 1, pp. 3-34.

55. Hoyos-Carvajal, L.; Bissett, J. Biodiversity of Trichoderma in neotropics. In The Dynamical Processes of Biodiversi-Ty-Case Studies of Evolution and Spatial Distribution; InTech: London, UK, 2011; pp. 303-320.

56. Kaushik, N.; Díaz, C.E.; Chhipa, H.; Julio, L.F.; Andrés, M.F.; González-Coloma, A. Chemical composition of an Aphid antifeedant extract from an Endophytic Fungus, Trichoderma sp. EFI671. Microorganisms 2020, 8, 420. [CrossRef]

57. Akmal, M.; Freed, S.; Malik, M.N.; Gul, H.T. Efficacy of Beauveria bassiana (Deuteromycotina: Hypomycetes) against different aphid species under laboratory conditions. Pak. J. Zool. 2013, 45, 71-78.

58. Liu, H.; Skinner, M.; Parker, B.L.; Brownbridge, M. Pathogenicity of Beauveria bassiana, Metarhizium anisopliae (Deutero-mycotina: Hyphomycetes), and other entomopathogenic fungi against Lygus lineolaris (Hemiptera: Miridae). J. Econ. Entomol. 2002, 95, 675-681. [CrossRef]

59. Wright, C.; Brooks, A.; Wall, R. Toxicity of the entomopathogenic fungus, Metarhizium anisopliae (Deuteromycotina: Hyphomycetes) to adult females of the blowfly Lucilia sericata (Diptera: Calliphoridae). Pest Manag. Sci. Former. Pestic. Sci. 2004, 60, 639-644. [CrossRef]

60. Ansari, M.A.; Vestergaard, S.; Tirry, L.; Moens, M. Selection of a highly virulent fungal isolate, Metarhizium anisopliae CLO 53, for controlling Hoplia philanthus. J. Invertebr. Pathol. 2004, 85, 89-96. [CrossRef] [PubMed]

61. Saranya, S.; Ushakumari, R.; Jacob, S.; Philip, B.M. Efficacy of different entomopathogenic fungi against cowpea aphid, Aphis craccivora (Koch). J. Biopestic. 2010, 3, 138.

62. Mweke, A.; Ulrichs, C.; Nana, P.; Akutse, K.S.; Fiaboe, K.K.M.; Maniania, N.K.; Ekesi, S. Evaluation of the Entomopathogenic Fungi Metarhizium anisopliae, Beauveria bassiana and Isaria sp. for the management of Aphis craccivora (Hemiptera: Aphididae). J. Econ. Entomol. 2018, 111, 1587-1594. [CrossRef] [PubMed] 